\title{
Does product complexity matter for firms' output volatility?
}

\author{
Daniela Maggioni ${ }^{\mathrm{a}, *}$, Alessia Lo Turco ${ }^{\mathrm{b}}$, Mauro Gallegati ${ }^{\mathrm{b}}$ \\ ${ }^{a}$ University of Catania, Department of Political and Social Sciences, Via V. Emanuele 8, 95100 Catania, Italy \\ b Polytechnic University of Marche, Department of Economics and Social Sciences, Piazzale Martelli 8, 60121 Ancona, Italy
}

\section{A R T I C L E I N F O}

Article history:

Received 10 March 2015

Received in revised form 13 March 2016

Accepted 14 March 2016

Available online 24 March 2016

\section{Keywords:}

Output fluctuations

Technological diversification

Human capital

Product market conditions

\begin{abstract}
A B S T R A C T
With this paper we provide the first micro-level evidence on the linkage between firm complexity and volatility. By defining product complexity à la Hausmann and Hidalgo (2009), we find that a higher complexity level of a firm's product basket is associated to a reduction of its output fluctuations. This evidence is robust to the control for omitted variables, sample selection, and to the use of alternative volatility and complexity indicators. Across similar firms, active in different sectors and regions, both technological factors and product market conditions explain the effect of complexity on volatility. However, within narrowly defined sectors and locations, the complexity-volatility nexus fully reflects the role of the human capital content of firms' product baskets.
\end{abstract}

(C) 2016 Elsevier B.V. All rights reserved.

\section{Introduction}

Does a country's specialisation in more complex goods affect the stability of its growth path? With this paper we aim at answering this question by adopting a micro-level perspective.

Existing literature on the topic defines complexity as technological diversification - i.e. the number of inputs used in production - and shows that there exists a direct effect of complexity on volatility at sector level, due to the lower exposition of technologically diversified sectors to input-specific external shocks (Koren and Tenreyro, 2013; Krishna and Levchenko, 2013). In this paper, instead, we extend the view on complexity from the sector to the product level by measuring product complexity à la Hausmann and Hidalgo (2009) and explore, for the first time to our knowledge, the relationship between complexity and volatility at the firm level. More specifically, we argue that firms producing goods that are more complex enjoy higher output stability.

The basic intuition behind the Hausmann and Hidalgo's, (2009) measure is that complex goods' production requires a wide set of diverse and exclusive capabilities. Hence, complex products are less ubiquitous not easily reproducible everywhere - and are generally produced by a few countries that can be considered complex on the basis of their large endowment of diverse and exclusive capabilities. As the notion of product and country complexity are therefore intertwined, Hausmann and Hidalgo (2009) propose and adopt the so-called Method of Reflections which iteratively combines information on countries' diversification and products' ubiquity retrieved from the world trade network to deliver a refined indicator of product complexity. The use of this complexity measure

\footnotetext{
* Corresponding author.

E-mail addresses: d.maggioni@univpm.it (D. Maggioni), a.loturco@univpm.it (A. Lo Turco), mauro.gallegati@univpm.it (M. Gallegati).
}

has the advantage to allow for enlarging the scope of the investigation on the possible drivers of the complexity-volatility nexus. Concerning technological factors, beyond the use of a wide variety of inputs which allows for better cushioning input-specific shocks, the stabilising role of complexity could reflect the higher human capital intensity of complex goods (Costinot, 2009; Krishna and Levchenko, 2013). A higher usage of both general and product specific human capital, indeed, by lowering learning costs and granting more flexibility in production, could make output of more complex firms less volatile. Furthermore, a relevant role could be played by product specific market conditions. We, therefore, consider the possible high incidence of fixed and sunk costs in complex goods' production which could act as a relevant entry barrier. Complex goods' producers could, then, face less competition and, hence, higher stability of their sales. Finally, we focus on possible demand side factors. More specifically, we inspect the contribution of goods' price and income elasticities. Complex goods, generally, are less substitutable and are purchased by high-income countries and, within countries, by those segments of consumers which are less exposed to shocks and guarantee a more stable demand. As their consumers are less sensitive to price and to income shocks, more complex goods could then present lower demand and, hence, production fluctuations. In this respect, Kraay and Ventura (2007) predict a higher relevance of product demand elasticity rather than labour supply elasticity in driving countries' aggregate volatility. ${ }^{1}$

\footnotetext{
${ }^{1}$ More in detail, Kraay and Ventura (2007) have calibrated a model in which rich countries specialise in more technological and skilled labour intensive sectors. As their industries face inelastic product demands and labour supplies, country-specific supply shocks have moderate income effects. The opposite is true in poor countries. From their model, differences in demand elasticity emerge as more important than differences in labour supply elasticity in the explanation of the heterogeneous volatility level across countries.
} 
The focus of our empirical analysis is on Turkish manufacturing firms between 2003 and 2008. By exploiting detailed information on firms' export baskets we infer the level of their product complexity and test the latter as a determinant of firms' output growth volatility. We believe that the Turkish manufacturing sector represents a particularly suitable context for the topic under investigation. Firm level dynamics are more relevant for the macroeconomics of smaller and emerging countries, where few firms account for the lion's share in the economy, and the economic structure is fragile and exposed to external shocks. Furthermore, the Turkish emerging economy represents an interesting case to study due to its recent economic evolution. During the last decades it has experienced dramatic changes in its production structure (Hidalgo, 2009), sustained growth and a rapid and increasing integration in the world trade network. Hence, we expect such a dynamic context to deliver important insights on the firm level complexity-volatility nexus under analysis.

Anticipating our findings, our empirical work delivers a negative association between production complexity and firm volatility. Across countries, differences in comparative advantage in more complex sectors hinge on international differences in institutional quality and human capital endowments (Costinot, 2009; Nunn, 2007; Levchenko, 2007). With our firm level analysis, instead, we highlight that, absent any difference in institutions and access to production factors, product complexity is still an important source of heterogeneity across very similar - in terms of productivity, size, etc. - firms active within very narrowly defined sectors and territories and significantly affects their growth stability. This result is robust to a plethora of checks, in particular to the control for sample selection, further volatility determinants and to the adoption of alternative volatility measures. When inspecting the factors explaining our main result, we find that within narrowly defined sectors and locations the positive association between complexity and output stability is driven by the implicit human capital content of firms' production.

By investigating the relationship between complexity and volatility our work is close to recent literature on the relationship between the nature of countries' production specialisation and volatility. Koren and Tenreyro (2007) relate the higher volatility of poor countries to their production patterns. Countries when developing tend to diversify their production, thus reducing their volatility. However, after a certain income level threshold, diversification decreases, thus confirming the U-shaped relationship between specialisation and development (Imbs and Wacziarg, 2003), but this goes with a further reduction of volatility because more developed countries tend to increase their specialisation in less volatile sectors. ${ }^{2}$ More specifically, Koren and Tenreyro (2013) highlight the role of the implicit technological diversification of countries' production structure in explaining the relationship between volatility and development. By the same token, (Krishna and Levchenko, 2013) show that more complex - technologically diversified - sectors present lower volatility of labour productivity. The higher stability of developed countries, therefore, rests on their comparative advantage in more complex goods. This specialisation pattern would stem from the availability of better institutions and higher human capital endowment. While the former allows to easily deal with the problem of imperfect contract enforcement, which particularly affects those productions requiring a larger number of inputs and contracts (Nunn, 2007; Levchenko, 2007), the latter entails lower learning costs which are relatively more important in complex productions (Costinot, 2009). The evidence on the complexity-volatility nexus at the aggregate country level, recalls the unambiguous and robust finding delivered by an important strand of literature in economic growth: the complexity level

\footnotetext{
2 This is consistent with findings by di Giovanni and Levchenko (2011) who show that countries are characterised by heterogeneous levels of export risk content according to their export basket composition. As a consequence, some countries can be specialised in low risky sectors, thus recording low variation in their growth even if their production is concentrated in a few sectors.
}

of countries' production specialisation - whether captured by the income/productivity content of their exports or by their capabilities content - explains countries' growth paths (Hausmann et al., 2007; Hausmann and Hidalgo, 2009). If complexity is positively related to a country's growth and negatively related to volatility, it then emerges as a possible driver behind the negative nexus between volatility and country development generally found in the literature. In this respect, our work contributes to build a bridge between the empirical literature showing the negative association between output volatility and economic growth (Ramey and Ramey, 1995; Hnatkovska and Loayza, 2004; Norrbin and Yigit, 2005; Lin and Kim, 2014) and the one disclosing the positive impact of export complexity on countries' development (Hausmann et al., 2007; Poncet and de Waldemar, 2013).

The work is structured as follows: the next section presents the product complexity measures we rely upon in the empirical analysis below, describes the data sources and our estimation sample. Section 3 presents the empirical model and reports our baseline results and robustness checks. Finally, in Section 4 we look for the drivers behind the complexity-volatility nexus and Section 5 concludes.

\section{Measurement issues and data}

\subsection{Measuring product complexity}

To measure firm product complexity we build on the measure proposed by Hausmann and Hidalgo (2009). ${ }^{3}$ Their basic intuition stems from Adam Smith's view on the wealth of nations. Wealth originates from the division of labor which, however, is limited by the extent of the market. It follows that wealth and development are related to the complexity that emerges from the interactions between the increasing number of individual activities that make up an economy. Hence, the persistence of cross-country differences in per capita income can be explained by differences in economic complexity, as measured by the diversity and exclusivity of capabilities present in a country and the interactions among them. Nonetheless, measures capturing countries' capabilities endowments are scarce. Hausmann and Hidalgo (2009) propose to infer on the set of capabilities a country is endowed with by means of the range of products it produces. Using their Lego analogy, a product is equivalent to a Lego model, and a country is equivalent to a bucket of Legos. Countries will be able to make products for which they have all the necessary capabilities, that is all the necessary Lego pieces. Hence, connections between countries and products signal the availability of capabilities in a country just like the creation of a model by a child signals the availability of a specific set of Lego pieces. In this respect, assessing the extent of a countries economic complexity on the basis of their product baskets is like inferring on the extent of diversity and exclusivity of the Lego pieces inside a bucket by only looking at the models that a group of children, each with a different bucket of Legos, can make.

More complex products, then, are defined as those requiring a specific set of diverse capabilities. As a consequence, they are not easily reproducible everywhere and are generally produced by a few countries endowed with a large set of diverse capabilities and with the ability to suitably combine them. This implies that, a highly complex economy, rather than being just diversified, produces a large number of less ubiquitous products, as well as a complex good is produced by a few countries that are also complex in the sense that they are endowed with a wide set of specific capabilities, as reflected by their production

\footnotetext{
${ }^{3}$ It is worth stressing that the complexity of a product differs from the notion of quality. The ranking of products on the basis of quality necessarily implies dealing, both conceptually and empirically, with the comparison of different varieties of the same product. On the contrary, when we rank products on the basis of their complexity, we can compare products that can be very different in terms of use and, as such, can by no means be compared in terms of quality. Hence, the scope of the comparison in terms of complexity is wider and, nonetheless, it can partially capture, yet not identify, a higher quality level of products when the latter translates in a higher number of capabilities needed to produce them.
} 


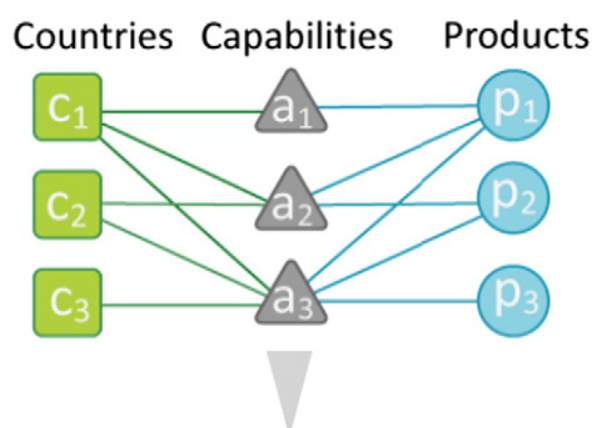

Countries Products

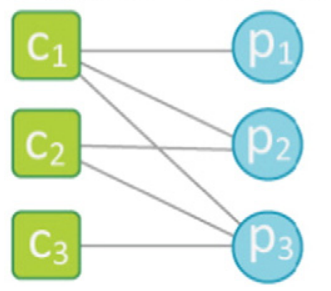

Fig. 1. The bipartite network of world trade as the result of a tripartite network connecting countries, capabilities and products Source: Hausmann and Hidalgo (2009)

of a large number of less ubiquitous products. Therefore, as the notion of product and country complexity are intertwined, in order to reproduce this logical setting, Hausmann and Hidalgo (2009) propose the so-called Method of Reflections which iteratively exploits information gathered from the bipartite (country-product) network of world trade on countries' diversification and products' ubiquity. The fundamental assumption is that this network is the reduced form of an unobservable tripartite network connecting countries to the capabilities they have and products to the capabilities they require (see Fig. 1).

The first step of the proposed methodology consists in empirically identifying the bipartite country-product network by selecting those products in which countries enjoy a Revealed Comparative Advantage (RCA). The RCA indicator measures the extent of countries' trade specialisation in a product vis-à-vis the rest of the world. A country exports a product $p$ with RCA when its export share in that product is higher than or equal to the corresponding world share (Balassa, 1965). ${ }^{4}$ The second step consists in defining the two basic notions of country diversification, $K_{c, 0}$, as the number of products a country $c$ exports with RCA, and of product ubiquity, $K_{p, 0}$, as the number of countries exporting a product $p$ with RCA. Both measures are calculated as follows:

COUNTRY DIVERSIFICATION : $K_{c, 0}=\sum_{p} d_{R C A} c p$

PRODUCT UBIQUITY : $K_{p, 0}=\sum_{C} d_{R C A} c p$

that is, summing over products and countries, respectively, the RCA dummy, $d_{R C A}$, which is equal to 1 for product $p$ a country exports with RCA and zero otherwise.

${ }^{4}$ Namely, the RCA index of country $c$ in product $p$ is calculated as

$R C A_{c p}=\frac{\frac{\text { country } c^{\prime} \text { s exportsofproduct } p}{\text { totalcountry } c^{\prime} \text { s exports }}}{\frac{\text { worldexportsofproduct } p}{\text { worldtotalexports }}}$ with $0 \leq R C A<\infty$

Hence, country $c$ exports product $p$ with RCA if the RCA index for the product is higher than or equal to 1 which, indeed, represents the neutrality threshold. Considering only countries' exports with RCA ensures that the metrics used to describe the network are not biased by countries' size.
The Method of Reflections, then, consists in an iterative procedure which combines information on products' ubiquity and countries' diversification in order to refine the rough complexity indicators in 1 and 2.

Hence, $K_{c, 0}$ and $K_{p, 0}$ are combined in a number of succeeding iterations and after $n$ iterations, these measures are then given by:

$$
\begin{aligned}
& K_{c, n}=\frac{1}{K_{c, 0}} \sum_{p} d_{R C A c p} * K_{p, n-1} \\
& K_{p, n}=\frac{1}{K_{p, 0}} \sum_{c} d_{R C A ~ c p} * K_{c, n-1}
\end{aligned}
$$

The basic intuition of the method is that in succeeding iterations one can add information about the extent of ubiquity of the products a country produces to the original information on its diversification and, by the same token, the information on products' ubiquity can be refined by adding information on the nature of diversification of countries exporting them. More specifically, at the $n^{\text {th }}$ iteration product complexity corrects the $K_{p, 0}$ product ubiquity indicator by taking into account information on country complexity, $K_{c, n-1}$, gathered by the $(n-1)^{\text {th }}$ iteration, which, in turn, reflects countries' specialisation in diverse and less ubiquitous products. Iterations stop when no more information can be drawn and indicators obtained by the $n^{\text {th }}$ and $n+1^{\text {th }}$ iterations converge to a stable ranking of products and countries. For the country level index, even numbered iterations give refined measures of country complexity, while odd numbered iterations deliver measures of countries' specialisation in few and highly ubiquitous products. Similarly, for the product level index, even numbered iterations give refined measures of a product's ubiquity, while odd numbered iterations give refined measures of the diversification of its exporters. The two indicators identify, then, a country's complexity by means of its specialisation in products that are not only less ubiquitous but also exported by more complex countries - which export a larger number of less ubiquitous products - and a product's complexity by means of its presence in the export basket of fewer countries that are complex. In this respect, a country's extent of complexity is reflecting something more than its raw export diversification. That is, the most diversified countries do not necessarily produce and export the most complex products, as the most complex economies do not necessarily need to be the most diversified ones. More specifically, if a highly diversified country, recording a high $K_{c, 0}$ index, is mostly specialised in highly ubiquitous - low value for odd iterations of $K_{p}$ - products, its level of complexity measured by the even iterations of the $K_{c, n}$ index will be low. ${ }^{5}$

In order to measure firms' product complexity we then build on these metrics that we compute for year 2002 at 6 digit-HS 1996 product level by exploiting BACI export data, collected by CEPII and available for a large number of countries. In particular, we focus on the standardised

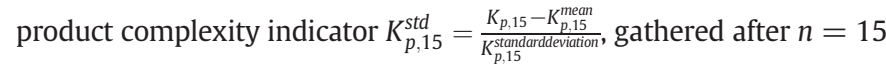
iterations.

To grasp the relevance of the Method of Reflections in defining a measure of product complexity by refining the simple product ubiquity measure, Table 1 shows 5 products with the highest and lowest values of $K_{p, 15}^{\text {std }}$ indicator and, for comparison, their corresponding simple ubiquity measure $K_{p, 0}$. It is worth highlighting that, as reported in the bottom of the Table, the iteration procedure delivers a very detailed ranking of products with 5111 different positions for each of the 5111 HS products, whereas the simple product ubiquity measure

\footnotetext{
${ }^{5}$ Therefore, the notion of complexity we rely upon in this work is not in contrast with the evidence of a hump in the relationship between export/production diversification and economic development which predicts a higher diversification level for middle income economies rather than for richer countries (Imbs and Wacziarg, 2003; Cadot et al., 2011). Our measure is, indeed, consistent with the work by Koren and Tenreyro (2007) who, while confirming the U-shaped relationship between specialisation and development, also show the existence of a positive monotone relationship between development and the risk content of countries' production specialisation.
} 
Table 1

HS product ranking according to $K_{p, 15}^{s t d}$

\begin{tabular}{|c|c|c|c|}
\hline Product description & $\begin{array}{l}\text { HS } \\
\text { code }\end{array}$ & $K_{p, 15}^{s t d}$ & $K_{p, 0}$ \\
\hline \multicolumn{4}{|l|}{5 products with the highest $K_{p, 15}^{s t d}$ values } \\
\hline $\begin{array}{l}\text { Machine-tools for dry-etching patterns on } \\
\text { semiconductor materials }\end{array}$ & 845691 & 3.068 & 2 \\
\hline Products electrolytically plated or coated with zinc & 722591 & 2.513 & 4 \\
\hline Ion implanters for doping semiconductor materials & 854311 & 2.506 & 4 \\
\hline Printing machinery & 844319 & 2.485 & 5 \\
\hline $\begin{array}{l}\text { Optical instruments \&appliances for inspecting } \\
\text { semiconductor wafers or devices }\end{array}$ & 903141 & 2.481 & 3 \\
\hline \multicolumn{4}{|l|}{5 products with lowest $K_{p, 15}^{\text {std }}$ values } \\
\hline $\begin{array}{l}\text { Plywood consisting solely of sheets of wood with at } \\
\text { least one outer ply of tropical wood }\end{array}$ & 441213 & -2.564 & 18 \\
\hline Karite nuts & 120792 & -2.641 & 7 \\
\hline Vegetable textile fibres & 530529 & -2.624 & 3 \\
\hline Raw sisal and other textile fibres of the genus agave & 530410 & -2.694 & 8 \\
\hline Jute and other textile bast fibres, raw or retted & 530310 & -3.021 & 8 \\
\hline \multicolumn{4}{|l|}{ Summary statistics of $K_{p, 15}^{s t d}$ and $K_{p, 0}$} \\
\hline Number of ranks & & 5111 & 73 \\
\hline Mean & & 0 & 19.81 \\
\hline Median & & 0.08 & 17 \\
\hline Minimum & & -3.02 & 1 \\
\hline Maximum & & 3.07 & 84 \\
\hline
\end{tabular}

$K_{p, 0}$ ranks the 5111 HS products into 73 classes only, each denoted by the number of countries exporting that product with RCA. As a matter of fact, from the Table we can observe two distinct values of $K_{p, 15}^{\text {std }}$ for "Products Electrolytically Plated Or Coated With Zinc" and "Ion Implanters For Doping Semiconductor Materials", despite they share the same number of exporters with RCA, that is 4 . Also, as revealed by the lower part of the Table the iteration procedure allows for a more precise ranking of less ubiquitous products. As an example, "Karite nuts" are only exported with RCA by 7 exporters and this would make of them a low ubiquity - potentially more complex - product in the lowest $5 \%$ of the product ubiquity distribution. Nonetheless, the iteration procedure, by complementing the information on product ubiquity with the one on the complexity of exporters, correctly classifies "Karite nuts" in the lowest part of the complexity ranking. The same is true for "Vegetable textile fibres", that, despite being exported with RCA by 3 countries only, show a very low value of the complexity indicator.

It is worth mentioning that our complexity indicator is highly correlated - roughly 0.75 - with the PRODY index proposed by Hausmann et al. (2007), where a product's complexity is measured as the average per capita income level associated with that product. Here, each exporter's per capita income level is weighted by means of its RCA index in the product. Indeed, after removing the information on per capita income, $P R O D Y$ collapses to $K_{p, 1}$ and this means that an important source of variation in the $P R O D Y$ indicator is driven by the structure of the network connecting countries to the products they export, rather than by the income of countries. Hence, the explanatory power that this complexity measure and its country level counterpart, EXPY, have demonstrated (Hausmann et al., 2007; Rodrik, 2006) stems from the information on the diversification of countries and on the ubiquity of products (Hidalgo, 2009), which we therefore fully exploit by means of our product complexity indicator. ${ }^{6}$ Removing the information on countries' income, then, delivers a more parsimonious metric. The latter has the further advantage to avoid potential measurement biases when less complex products are mostly exported with RCA by a few high income economies, due to their natural comparative advantages or their specific preferences and consumption habits. In this case, the information on income would create an upward bias in the PRODY index

\footnotetext{
${ }^{6}$ Poncet and de Waldemar (2013) use Hausmann and Hidalgo's indicator of economic complexity to measure the extent of export sophistication in China. They find that cities' economic complexity is a much more robust growth determinant than is export complexity measured à la Hausmann et al. (2007).
}

which can be sensitively reduced by exclusively combining information on products' ubiquity and countries' diversification in the Method of Reflections. Although this is a minor concern for manufacturing goods, it could be a relevant mismeasurement issue for primary goods. ${ }^{7}$

Finally, before pursuing our empirical analysis, it is worth stressing that our indicator has the shortcoming of being an ex-post measure of complexity whose real sources, i.e. firms' endowment of capabilities, remain unmeasured. Nonetheless, this potential shortcoming could yet make the indicator more attractive, as it has the ability to capture and combine different features of our notion of complexity. Throughout our empirical analysis we will shed light on the factors driving the volatility-complexity nexus. On one hand, product complexity could reflect different product technological characteristics, such as technological diversification, the need for specific investments or a higher human capital content. On the other hand, it could also reflect a product's market conditions, such as the extent of competition in supply, the income and price elasticity of demand. All these elements, indeed, could be related to products' capability content and translate into the fact that just a small number of countries are able to produce and export (with comparative advantage) them, and that these countries present a high level of product diversification.

\subsection{Firm level Measures, data sources and descriptive statistics}

In order to compute complexity at the firm level, we exploit information on firms' export product baskets. Hence, we assume that firms' export goods are a valid proxy of their overall production. ${ }^{8}$ Hinging on the complexity indicator presented in the previous section we, then, measure firm $i$ 's export

$K_{i}=\frac{\sum_{p=1}^{P_{i}} K_{p, 15}^{s t d}}{P_{i}}$

where $P_{i}$ is the number of products exported by firm $i{ }^{9}$

Turning to our dependent variable, we measure output volatility, gvol, as the log standard deviation of firms' yearly output log growth rates (Koren and Tenreyro, 2013; di Giovanni and Levchenko, 2012) over a 5 -year time span. Output is calculated by deflating turnover by means of 4 digit sector level production price indexes and correcting for changes in inventories. ${ }^{10}$ The use of a 5-year, or slightly longer, period for the computation of volatility is pretty standard in the micro-level literature on output fluctuations, due to the limited time spans typically available in firm level panel data. ${ }^{11}$

It is worth mentioning that the focus on the manufacturing sector is of particular relevance for an emerging country such as Turkey. As a

\footnotetext{
7 As an example, consider the case of exports of salmon by baltic countries or of purebred breeding horses by U.K, U.S.A. and United Arab Emirates. For the case of salmon, indeed, - HS code 030212 "Pacific Salmon, Atlantic Salmon and Danube Salmon" - the corresponding income level associated by the PRODY in 2002 is $\$ 36,927$, therefore the product ranks $7^{\text {th }}$ in terms of the PRODY index. More intuitively, according to the $K_{p, 15}^{\text {std }}$ indicator, instead, the product ranks 1614, preceded by "Meat and edible meat offal, salted, in brine, dried or smoked" and followed by "Malt". As far as pure-bred breeding horses HS code 010110 - are concerned, they rank $3^{\text {rd }}$ according to the PRODY index as they have an average income level of $\$ 41,100$, nonetheless the $K_{p, 15}^{s t d}$ indicator, as for the case of salmon, more correctly classifies horses in the second quartile of the complexity distribution.

${ }^{8}$ In the following we will, then, test the sensitivity of our results to this assumption.

${ }^{9}$ In the robustness checks we will also experiment a weighted average complexity using the value of product $p$ exported by firm $i$.

10 We decided to limit our analysis to the period 2003-2008, thus excluding the 2009 global crisis year which could distort the linkage between micro level complexity and volatility in a short-time span (Lo Turco and Maggioni, 2014).

11 Buch et al. (2009) analyse standard deviations of output growth over rolling five-year windows for German firms. Vannoorenberghe (2012), on an unbalanced panel for the period 1998-2007, considers all firms with at least 5 years of information of output growth. (Kalemli-Ozcan et al., 2014) investigate the standard deviation of growth over the years 2002/2008 for firms in 16 European countries. Finally, (García-Vega et al., 2012) also focus on volatility computed on 5 -year time spans.
} 
matter of fact, manufacturing has a growing role in emerging markets' economies, and thus largely contributes to aggregate volatility. ${ }^{12}$ In particular, the correlation between firm level and aggregate two digit sector level output volatility in Turkish manufacturing is around 0.60 , thus pointing at the relevance of micro-level output dynamics for the country's aggregate phenomena.

All firm level data we use in this work originate from the matching of Turkish Structural Business Statistics (SBS) and Foreign Trade Statistics provided by the Turkish Statistical Office (TurkStat). The first source provides data on output, input costs, employment, NACE rev 1.1 sector of activity and NUTS III region of location over the period 2003-2008 for the whole population of firms with more than 20 employees and for a representative sample of firms with less than 20 employees. The second one, instead, provides information on firms' export and import activities for the period 2002-2008. Firm foreign trade flows by origin/ destination are recorded at 12-digit of the GTIP classification, whose first six digits correspond to HS. This allows us to easily compute for each firm its product complexity indicator by directly matching information in HS from BACI with our micro-level information on firms' HS export codes. ${ }^{13}$ We are, then, able to measure complexity for about 5000 different product classes. This ensures a high variation across firms, even within narrowly defined sectors, in terms of their product basket complexity. This extent of detail is not achievable with production data in our case. As a matter of fact, firm-product - 10 digit PRODTR classification - level data are available, for the period 20052009, from Turkish Annual Industrial Production Statistics (AIPS) for all - both exporting and non exporting - manufacturing firms with more than 20 persons employed. In order to calculate product complexity the PRODTR has to be harmonised with HS, which means measuring complexity for a lower - about 1000 - number of aggregated product categories. This implies a loss of information compared to the use of export data. Furthermore, output growth rates for firms in the AIPS can only be calculated for a 3 year time span. For these reasons, we decided to rely on export data to proxy firms' product complexity through all our empirical analysis and leave the use of production data as robustness check of our main findings.

Our analysis is run on all Turkish manufacturing firms ${ }^{14}$ with more than 20 employees exporting in 2002 and whose economic activity, in terms of total (export and domestic) turnover, was continuously observed in the 2003-2008 year time span.

Our final ${ }^{15}$ sample of 4174 firms represents roughly $47 \%$ of total manufacturing employment referrable to Turkish firms with more than 20 employees and about $55 \%$ of their total output. When considering only the population of Turkish firms exporting manufacturing products in 2002 and employing more than 20 employees, our sample accounts for about $73 \%$ of their total employment and $78 \%$ of their total output. Table A. 1 in Appendix A describes our sample composition in terms of NACE sectors. Half of the sample belongs to the Turkish main comparative advantage sectors, such as Food (15), Textiles (17), Apparel (18) and Mechanical Machinery (29). Nonetheless, the

\footnotetext{
12 (Koren and Tenreyro, 2007) show that manufacturing sectors present intermediate levels of volatility compared to the agriculture sector, which is characterised by the highest volatility, and the services which are characterised by lower fluctuations.

13 While firm level trade data are available in HS2002 and HS2007, CEPII data used to compute aggregate product complexity measures are available in HS1996. A harmonised classification was then created.

${ }^{14}$ We only exclude about 60 firms that are recorded in manufacturing NACE Rev 1.1 sectors 16 and 23.

${ }^{15}$ We excluded outliers by trimming our data at $0.5 \%$ below and above the volatility and the complexity distributions. When we used alternative data cleaning procedure the insights from the following analysis remain unchanged. In particular: i) we winsorised the data $1 \%$ above and below the volatility and complexity distribution; ii) we winsorised the data 5\% above and below the volatility and complexity distribution; iii) we trimmed the data $1 \%$ above and below the volatility and complexity distribution; iv) we applied no cleaning at all; v) we reintroduced sectors 16 and 23; vi) we reintroduced sectors 16 and 23 and applied no cleaning at all.
}

remaining sectors display a non-negligible size in terms of total number of firms, hence witnessing a certain degree of diversification of the Turkish emerging economy. The distribution of firms by region displayed in Table A.2 in Appendix A reproduces the typical territorial pattern of industrial activities in emerging economies like Turkey. Nearly half of our sample firms are located in Istanbul and less developed Eastern regions (roughly from code 61 to C3 in the Table) are of minor importance as they account for about $10 \%$ of total firms in our sample.

Table 2 presents some descriptive statistics of firm characteristics, all measured in the first year of our sample, that is 2003. Besides statistics on complexity and volatility we present a number of further firm level variables that will serve as controls in our benchmark estimations. They are all measured in the base year 2003 and are: size, Size, measured as the log number of employees; labour productivity, Labour Productivity, measured as log of value added over number of persons employed; log of average wage, Wage; import status, Importer, measured as a dummy variable equal to one if firm reports positive imports and to zero otherwise; investments in tangible, Investor ${ }^{\text {Tangibles }}$, and intangible, Investor ${ }^{\text {Intangibles }}$, assets, measured by means of dummy variables equal to one when the firm reports a non zero value of investments and zero otherwise. Tangible investments include investments in land, estates, building and civil engineering structures, transportation vehicles, machineries, equipments and computers. Intangibles investments, instead, refer to computer software, licences, trademarks, patent rights, $\mathrm{R} \& \mathrm{D}$ expenses. Also, we report the statistics for average output log growth rates, Average growth, and average export log growth rates, Average growth ${ }^{\text {Exports }}$, in the period 2004-2008. The Table shows that output volatility varies substantially across firms. Also, a large heterogeneity exists in product complexity across firms' export baskets. Average firm product complexity, measured in the pre-sample year 2002 as from the above Eq. (3), reveals that Turkish firms actually export products that are less complex than the world average. Furthermore, it turns out that exports have experienced a poorer performance than total output and are characterised by a higher variation. As our sample is made up of exporters, firms are on average larger compared to the average size of Turkish manufacturing firms and importers constitute $84 \%$ of our observations. Investors in tangible assets are about $81 \%$, while investors in intangibles only represent one third of the total sample.

Turning to the relationship between firm complexity and volatility, from Fig. A.1 in the Appendix A it emerges that more and less complex firms differ all along the whole volatility distribution. The kernel distributions of output volatility for firms with high (above the median) and low (below the median) complexity levels, $K$, in 2002 reveal that more complex firms appear to be systematically less volatile and this evidence is confirmed by a two-sample Kolmogorov-Smirnov test for

Table 2

Evolution of firm volatility and export complexity.

\begin{tabular}{llrcrr}
\hline Variable & Obs & \multicolumn{1}{c}{ Mean } & Std. dev. & \multicolumn{1}{c}{ Min } & \multicolumn{1}{c}{ Max } \\
\hline gvol & 4174 & -1.34 & 0.62 & -2.97 & 0.50 \\
K & 4174 & -0.232 & 0.90 & -2.23 & 2.32 \\
Average growth $_{\text {Average growth }}^{\text {Exports }}$ & 4174 & 0.054 & 0.161 & -1.051 & 0.657 \\
Size & 3857 & -0.001 & 0.702 & -2.689 & 2.178 \\
Labour productivity $_{\text {Wage }}^{4174}$ & 4.35 & 1.02 & 2.08 & 9.75 \\
Importer $_{\text {Investor }}^{\text {Tangibles }}$ & 4055 & 9.74 & 1.13 & 1.39 & 14.08 \\
Investor $^{\text {Intangibles }}$ & 4174 & 8.85 & 0.58 & 7.17 & 12.09 \\
\hline SOurce: TurkStat & 4174 & 0.84 & 0.37 & 0 & 1 \\
& 4174 & 0.81 & 0.39 & 0 & 1 \\
\hline
\end{tabular}

Source: TurkStat SBS and FTS. Own calculations.

Average growth and Average growth ${ }^{\text {Exports }}$ are log growth rates of output and exports and refer to the period 2004-2008. $K$ is measured in the pre-sample year 2002. The remaining variables refer to 2003.

Average growth ${ }^{\text {Exports }}$ is missing for some observations, since few firms in our sample of 2002 exporters stop to export after 2004. 
equality of distribution functions. ${ }^{16}$ More specifically, Table 3 shows correlations between complexity and volatility and all firm controls we consider in our benchmark specification together with the inclusion of firm average growth. Volatility is negatively correlated with all the firm level characteristics, particularly size and wages. Hence, more stable firms seem to be larger and more productive. On the contrary, firm complexity is positively correlated with all firm characteristics, except size. In particular more complex firms are more productive and pay higher wages. Interestingly enough, we find a negative correlation between firm volatility and growth, thus corroborating at the micro level the evidence of a positive association between growth stability and the growth path. Furthermore, we disclose a positive correlation between firm growth and export basket average complexity and a negative correlation between the latter and volatility. This pattern recovered from simple pairwise correlations, suggests a picture where higher growth rates are achieved by higher complexity firms and the latter also experience a smoother growth path. To better understand this evidence and motivate the following empirical analysis, we explore the relationship between firm overall output growth, volatility and complexity in Table A.3 in Appendix A. Here, controlling for the initial - in 2003 - output level and for NACE 4 digit sector and NUTS 3 region fixed effects, we find that, when independently tested, firm complexity is positively associated to firm - either average or median growth, while volatility is negatively associated to growth. When both measures are tested jointly, it emerges that both the size and significance of the complexity coefficient shrink, whereas the significance of the volatility coefficient stays unchanged. ${ }^{17}$ This evidence actually suggests that product complexity could be a relevant factor behind the volatility-growth nexus. Hence, in the following we test and explore at the firm level whether a higher production complexity favours a more stable growth path.

\section{The empirical analysis of the firm level complexity-volatility nexus}

\subsection{Empirical model and baseline evidence}

To investigate the complexity-volatility nexus we estimate the following empirical model by means of OLS:

$\operatorname{gvol}_{i, 2008 / 2004}=\alpha+\beta K_{i, 2002}+\omega X_{i 2003}+\gamma_{j}+\eta_{r}+\varepsilon_{i}$

where gvol represents firm $i$ 's output growth volatility, which, as previously mentioned, is calculated as the logarithm of the standard deviation of growth rates measured on output levels observed in the 2003-2008 period. $X$ is a set of relevant firm characteristics, all measured in the base year 2003. Finally, in the model, $\gamma_{j}$ and $\eta_{r}$ represent 4-digit NACE sector and a NUTS III region fixed effects, respectively. Our interest is on the coefficient associated to $K$, that is firm $i$ 's export complexity. As previously mentioned, $K$ is measured in the pre-sample year 2002 in order to attenuate reverse causality issues.

Table 4 shows the baseline results on the relationship between firm export complexity and output volatility in columns [1] to [3]. Our preferred specification is the one in column [3] where we include a bunch of relevant firm level controls. The message emerging from the estimates is clear: firms specialised in more complex goods present a higher stability of their overall sales. The inclusion of firm level covariates, in particular firm size, almost halves the raw association between complexity and volatility recorded in column [1]. Nonetheless, the latter preserves its high significance. We, therefore, argue that, even within narrowly defined sectors and territories, a higher product complexity

\footnotetext{
${ }^{16}$ Results of this test are not shown, but available from the authors upon request.

17 This evidence is confirmed when firm labour and investment dummies are included in the specification to proxy for production inputs. Results are not shown for brevity, but they are available from the authors upon request.
}

turns into lower volatility. Then, firm product complexity emerges as a further important heterogeneity dimension across very similar firms in terms of location, sector of activity, size and other relevant features. Turning to the remaining firm controls, it is worth highlighting that the result on size mimics the coefficient estimates available in the literature stemming from a log-log specification of the relationship between firm size and volatility (Stanley et al., 1996; Sutton, 2002). Labour productivity is not significantly related to firm volatility, while importing or investing in tangible assets reduces volatility by $6.3 \%$ and $11 \%$, respectively. The result on import status could originate from productivity gains enjoyed by importers if foreign markets provide firms with the opportunity to exploit a higher variety of inputs and/or inputs characterised by a lower price and a higher technological/quality content. Furthermore, access to foreign input markets allows firms to cushion negative shocks in the domestic upstream sectors which may importantly and negatively affect firms' productive processes. Finally, firm average wage is also negatively related to growth volatility. A higher wage could reflect and capture the effect of a higher labour productivity. Indeed, Table 3 shows a positive and high correlation between labour productivity and average wage which, possibly exacerbated by the inclusion of the remaining controls, could explain the lack of significance of the former.

In order to grasp an idea of the magnitude of the effect, we take as reference the descriptive statistics shown in Table 2. A one standard deviation increase in complexity would reduce a firm's growth rate standard deviation roughly by $6 \%$, which corresponds to about $10 \%$ of the volatility variability. More intuitively, if a firm moved from the production of tungsten halogen lamps to the production of arc-lamps, its volatility would fall by around $5 \%$. Also, moving from the production of pocket-size radio cassette-players to radar apparatus or, alternatively, switching from artificial teeth fittings to apparatus for dental use based on the use of X-rays would, instead, deliver larger effects, as firm volatility would drop by $8 \%$ and $12.4 \%$, respectively.

Fig. A.2 in Appendix A shows the distribution of predicted volatility from estimates of model 4 under four alternative scenarios concerning firms' complexity level. First of all, we plot the distribution of predicted volatility for the observed firm complexity levels. Then, we explore how this distribution would change if all firms increased their complexity by one standard deviation. Finally, we plot the distribution under the two alternative hypothesis that all firms either reach the maximum or fall to the minimum level of complexity recorded in the sample. From the picture it emerges that only important changes in firms' complexity levels are able to considerably reduce their volatility. In this respect, this picture conveys an important message: large resources need to be devoted to the complexity upgrading of manufacturing production, as far as it becomes rewarding in terms of growth path stabilisation.

In columns [4]-[8] we inspect whether the complexity-volatility nexus somehow reflects the omission of relevant factors capturing the extent of firms' involvement in international markets. Empirical work has found a significant association between firm volatility and export intensities (Buch et al., 2009; Vannoorenberghe, 2012). Also, within narrowly defined sectors and regions, heterogenous firm complexity levels could well be related with different firm export shares if the domestic and foreign markets display different preferences for complex goods. Hence, in column [4] we test the inclusion of the export share among the right hand side determinants of volatility. A firm's higher exposure in international markets has no significant effect on its total output volatility and the size and significance of the complexity coefficient is unchanged compared to the baseline specification in column [3]. This finding is confirmed when we split firm exports according to the income level of destinations in column [5]. ${ }^{18}$

If more complex firms were exporting a higher share of their output to high income countries the coefficient found on export complexity

\footnotetext{
18 Export shares refer to year 2003, as information on output is only available after 2003.
} 
Table 3

Correlations

\begin{tabular}{|c|c|c|c|c|c|c|c|c|c|c|}
\hline & gvol & Average growth & Average growth ${ }^{\text {Exports }}$ & K & Size & Labour Productivity & Wage & Importer & Investor $^{\text {Tangibles }}$ & Investor $^{\text {Intangibles }}$ \\
\hline gvol & 1 & & & & & & & & & \\
\hline Average growth & -0.161 & 1 & & & & & & & & \\
\hline Average growth ${ }^{\text {Exports }}$ & -0.067 & 0.202 & 1 & & & & & & & \\
\hline K & -0.171 & 0.199 & 0.089 & 1 & & & & & & \\
\hline Size & -0.218 & -0.127 & $0.014^{n s}$ & $-0.033^{a}$ & 1 & & & & & \\
\hline Labour Productivity & -0.103 & -0.061 & $0.035^{a}$ & 0.127 & 0.155 & 1 & & & & \\
\hline Wage & -0.216 & $-0.006^{n s}$ & $0.052^{a}$ & 0.277 & 0.361 & 0.419 & 1 & & & \\
\hline Importer & -0.139 & -0.042 & $0.02^{n s}$ & 0.079 & 0.318 & 0.206 & 0.253 & 1 & & \\
\hline Investor Tangibles & -0.127 & $-0.0002^{n s}$ & $0.039 a$ & 0.054 & 0.156 & 0.072 & 0.16 & 0.125 & 1 & \\
\hline Investor Intangibles $^{\text {In }}$ & -0.112 & $0.006^{n s}$ & $0.038 \mathrm{a}$ & 0.074 & 0.305 & 0.179 & 0.29 & 0.159 & 0.313 & 1 \\
\hline
\end{tabular}

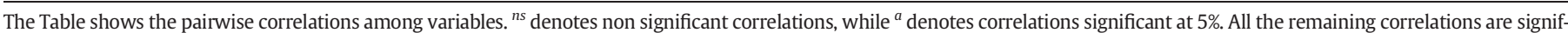
icant at $1 \%$ level.

could well reflect the lower consumption volatility of these markets. This is not supported by our findings. We find, indeed, that the inclusion of export intensities to rich and poor countries ${ }^{19}$ does not affect the size and significance of the coefficient of our main variable of interest. ${ }^{20}$

The number of export destinations and products could also affect the above shown complexity-volatility linkage. As in our definition more complex products are less ubiquitous, it is likely that more complex firms sell to multiple markets. Furthermore, they are expected to produce and export more products thanks to their wider capabilities endowment and higher organizational skills (Nocke and Yeaple, 2006). The estimated impact of complexity could, then, actually reflect a better ability of multiple-destinations/product exporters to arbitrate shocks across different markets. We, then, include the number of export destinations, $N^{\text {Destinations }}$, and find that it is actually negatively related to volatility. ${ }^{21}$ We further show that the number of exported products, $N^{\text {Products }}$, is negatively associated with firm volatility. Nonetheless, in columns [6]-[8] our main result is confirmed and appears to be independent of the extent of export diversification. Also, the latter seems to mainly reflect the importance of market, rather than product, diversity. ${ }^{22}$

In conclusion, the negative relationship between exporters' specialisation in complex goods and volatility seems to be robust to and independent on firms' export intensities and export basket composition in terms of number of products and destination markets. As a consequence, we expect such positive linkage between stability and production complexity to hold regardless of a firm's presence in the export market. To validate this hypothesis, we repeat the baseline analysis by estimating a model of output volatility on the basis of production data available from TurkStat AIPS. We present estimates on output volatility by focusing on the $2006-2008$ period. ${ }^{23}$ Results are shown in Table A.4

\footnotetext{
19 We use the 2014 World Bank countries' classification to define high and low income countries. We classify in the former group all - both OECD and non OECD - high income countries, while the rest of the countries - upper medium, lower medium and low income countries - are classified as low income.

${ }^{20}$ It is worth mentioning that raw correlations between volatility and export shares are low and positive ( 0.05 for the total and high income export share and 0.02 for the export share to low income economies). Also, complexity shows a negative correlation with the total export share $(-0.10)$ and with the export shares to high income countries $(-0.20)$. Finally, there is a positive correlation $(0.15)$ between firm complexity and export share to low income economies.

21 This evidence also confirms the interpretation of the findings by Buch et al. (2009) who state that the lower volatility of exporters compared to non exporters could be due to the low correlation between domestic and foreign shocks which would lead to gains from diversification. While they are not able to empirically investigate this hypothesis, we show that exposition to a larger number of destinations reduces a firm's volatility, thus suggesting an imperfect correlation of shocks among different destination countries.

22 It is worth mentioning that the number of export destinations and products refer to year 2002. Also, insights from columns [6]-[8] are unaffected when we measure export concentration by means of the Herfindhal index calculated across destination markets or export products. Results are not shown for the sake of brevity, but they are available upon request.

${ }^{23}$ We obtain exactly the same insights when we calculate volatility as the standard deviation of raw production value as recorded in the AIPS, that is the value of all products produced in a year regardless of their accounting as changes in final or intermediate good inventories.
}

and reveal that the negative and significant coefficient on product complexity holds, regardless of a firm's export intensity. In particular, this finding is confirmed even when we interact product complexity by the export share to test for any differential impact of complexity according to the extent of involvement in international markets and, accordingly, for any differential impact of exporting stemming from heterogenous complexity levels across firms.

From this evidence we can conclude that product complexity matters for firms' growth stability beyond their involvement in exporting. Also, this test reveals that our findings are not driven by sample selection in terms of export activity.

\subsection{Further sensitivity analysis}

Table 5 shows that our baseline findings are robust to further checks. In column [1] we substitute averages of the regressors for their presample value. In this case, we focus on firms exporting continuously across all the sample years and we replace the dummies for investors in tangible and intangible assets with the average share of investments in tangible and intangible assets over output. In column [1] we adopt as alternative complexity indicator the PRODY index proposed by Hausmann et al. (2007), which, as mentioned above, reflects the income content of products. ${ }^{24}$ In column [3], we include ${ }^{25}$ firm average growth and in column [4] we interact the four digit sector fixed effects with the NUTS III region ones. In all cases the existence of a negative and significant relationship between complexity and volatility is confirmed.

In columns [5]-[9] we explore the robustness of this finding to the adoption of alternative measures of volatility. In particular, baseline results are corroborated in column [5] when we use the log of the squared residuals of a firm growth regression on time and firm fixed effects (Blanchard and Simon, 2001; Buch et al., 2009). Nevertheless, the significant association between past complexity and subsequent firm output growth volatility could be driven by the omission of the firm's past growth pattern. In other words, the fact that firms with heterogeneous volatility levels could sort themselves into products with different extent of complexity raises a serious concern on the existence and identification of our effect. On one hand, more stable firms could more easily

\footnotetext{
${ }^{24}$ Our main finding is corroborated when we use further alternative complexity proxies as: i) the export share of products with a complexity index above the median (or the 75th percentile) of the product complexity distribution; ii) the indicator we gather after an even-numbered iteration, $K_{p 12}$, which conveys information about the product's ubiquity and the ubiquity of related products which are exported - with RCA - by the same countries; iii) the relative export complexity measure obtained by dividing the firm product complexity by the 4-digit average complexity; iv) the measure of product ubiquity proposed by Tacchella et al. (2013) which adjusts the Hausmann and Hidalgo's definition of product complexity by accounting for the fact that if a poorly diversified country is able to export a given product, very likely this product has a low level of complexity.

${ }^{25}$ Results are robust even when we alternatively include further right hand side controls: i) a firm's average total export value; ii) a firm's average import complexity alone and together with the number of export products and destinations; iii) further firm leve controls as subcontractor, outsourcer, foreign ownership, multi-plant dummies and the firm's R\&D labour share.
} 


\begin{tabular}{|c|c|c|c|c|c|c|c|c|}
\hline & {$[1]$} & {$[2]$} & [3] & {$[4]$} & {$[5]$} & {$[6]$} & [7] & {$[8]$} \\
\hline & \multicolumn{3}{|l|}{ Baseline } & \multicolumn{5}{|c|}{ Controlling for firm export activity } \\
\hline K & $\begin{array}{l}-0.119^{* * * *} \\
{[0.021]}\end{array}$ & $\begin{array}{l}-0.080^{* * * *} \\
{[0.020]}\end{array}$ & $\begin{array}{l}-0.064^{* * *} \\
{[0.020]}\end{array}$ & $\begin{array}{l}-0.063^{* * *} \\
{[0.021]}\end{array}$ & $\begin{array}{l}-0.066^{* * * *} \\
{[0.021]}\end{array}$ & $\begin{array}{l}-0.067^{* * *} \\
{[0.020]}\end{array}$ & $\begin{array}{l}-0.066^{* * *} \\
{[0.020]}\end{array}$ & $\begin{array}{l}-0.067^{* * *} \\
{[0.020]}\end{array}$ \\
\hline Size & & $\begin{array}{l}-0.144^{* * * *} \\
{[0.010]}\end{array}$ & $\begin{array}{l}-0.113^{* * * *} \\
{[0.011]}\end{array}$ & $\begin{array}{l}-0.116^{* * *} \\
{[0.011]}\end{array}$ & $\begin{array}{l}-0.113^{* * * *} \\
{[0.011]}\end{array}$ & $\begin{array}{l}-0.094^{* * * *} \\
{[0.012]}\end{array}$ & $\begin{array}{l}-0.105^{* * *} \\
{[0.012]}\end{array}$ & $\begin{array}{l}-0.094^{* * *} \\
{[0.012]}\end{array}$ \\
\hline Labour_Productivity & & & $\begin{array}{l}-0.011 \\
{[0.009]}\end{array}$ & $\begin{array}{l}-0.009 \\
{[0.009]}\end{array}$ & $\begin{array}{l}-0.01 \\
{[0.009]}\end{array}$ & $\begin{array}{l}-0.007 \\
{[0.009]}\end{array}$ & $\begin{array}{l}-0.009 \\
{[0.009]}\end{array}$ & $\begin{array}{l}-0.007 \\
{[0.009]}\end{array}$ \\
\hline Importer & & & $\begin{array}{l}-0.063^{* *} \\
{[0.028]}\end{array}$ & $\begin{array}{l}-0.072^{* *} \\
{[0.028]}\end{array}$ & $\begin{array}{l}-0.065^{* *} \\
{[0.028]}\end{array}$ & $\begin{array}{l}-0.048^{*} \\
{[0.028]}\end{array}$ & $\begin{array}{l}-0.060^{* *} \\
{[0.028]}\end{array}$ & $\begin{array}{l}-0.048^{*} \\
{[0.028]}\end{array}$ \\
\hline Investor ${ }^{\text {Tangibles }}$ & & & $\begin{array}{l}-0.111^{* * * *} \\
{[0.026]}\end{array}$ & $\begin{array}{l}0.007^{* * *} \\
{[0.001]}\end{array}$ & $\begin{array}{l}-0.111^{* * *} \\
{[0.026]}\end{array}$ & $\begin{array}{l}-0.108^{* * *} \\
{[0.026]}\end{array}$ & $\begin{array}{l}-0.111^{* * *} \\
{[0.026]}\end{array}$ & $\begin{array}{l}-0.108^{* * *} \\
{[0.026]}\end{array}$ \\
\hline Investor $^{\text {Intangibles }}$ & & & $\begin{array}{l}0.015 \\
{[0.022]}\end{array}$ & $\begin{array}{l}0.112 \\
{[0.366]}\end{array}$ & $\begin{array}{l}0.015 \\
{[0.022]}\end{array}$ & $\begin{array}{l}0.02 \\
{[0.022]}\end{array}$ & $\begin{array}{l}0.017 \\
{[0.022]}\end{array}$ & $\begin{array}{l}0.02 \\
{[0.022]}\end{array}$ \\
\hline Wage & & & $\begin{array}{l}-0.088^{* * * *} \\
{[0.021]}\end{array}$ & $\begin{array}{l}-0.092^{* * *} \\
{[0.021]}\end{array}$ & $\begin{array}{l}-0.089^{* * * *} \\
{[0.021]}\end{array}$ & $\begin{array}{l}-0.077^{* * * *} \\
{[0.022]}\end{array}$ & $\begin{array}{l}-0.086^{* * *} \\
{[0.021]}\end{array}$ & $\begin{array}{l}-0.077^{* * *} \\
{[0.022]}\end{array}$ \\
\hline Export_Share & & & & $\begin{array}{l}0.029 \\
{[0.040]}\end{array}$ & & & & \\
\hline Export_Share High_Income $^{\text {Hign }}$ & & & & & $\begin{array}{l}0.005 \\
{[0.044]}\end{array}$ & & & \\
\hline Export_Share ${ }^{\text {Low_Income }}$ & & & & & $\begin{array}{l}0.152^{*} \\
{[0.092]}\end{array}$ & & & \\
\hline$N^{\text {Destinations }}$ & & & & & & $\begin{array}{l}-0.050^{\text {**** }} \\
{[0.010]}\end{array}$ & & $\begin{array}{l}-0.054^{* * *} \\
{[0.013]}\end{array}$ \\
\hline$N^{\text {Products }}$ & & & & & & & $\begin{array}{l}-0.022^{* *} \\
{[0.010]}\end{array}$ & $\begin{array}{l}0.006 \\
{[0.012]}\end{array}$ \\
\hline Observations & 4174 & 4174 & 4055 & 4055 & 4055 & 4055 & 4055 & 4055 \\
\hline R-squared & 0.183 & 0.226 & 0.238 & 0.236 & 0.239 & 0.243 & 0.239 & 0.243 \\
\hline
\end{tabular}

Notes: The dependent variable is the firm output volatility, gvol.

Robust standard errors in brackets. All specifications include 4 digit NACE Rev 1.1 sector and NUTS III region dummies.

* Significant at $10 \%$ level.

** Significant at $5 \%$ level.

*** Significant at $1 \%$ level.

start and continue more complex productions and this would imply a downward bias in our estimates. On the other hand, if higher firm volatility reflects lower risk aversion, then, more volatile firms could be more likely to start producing more complex goods and, in this case, we would underestimate the stabilising effect of product complexity. It is, then, important to account for autocorrelation in the observed firm's growth pattern to purge residuals from any unaccounted persistence in firms' growth rates. Although we are not able to account for firms' output growth patterns before 2003, we estimate a model of firm growth rates in the time span at our disposal where, besides firm and year fixed effects, we alternatively include the first and the second order autoregressive term. Our main findings are largely confirmed both when we consider the sample of firms surviving during the time window of five years that we chose as our baseline estimation sample (columns [6]-[7]) and when we expand the sample to all firms exporting in 2002, regardless of their survival (columns [8]-[9]). Therefore, we consider results in the last two columns of the Table as a test of the lack of sample selection stemming from considering only surviving firms in our baseline estimation sample. This empirical approach, by cleansing the turnover evolution from autocorrelation dynamics, together with the use of pre-sample measures of firm complexity, could suggest the existence of a causal nexus running from complexity to volatility. Furthermore, as when accounting for an autoregressive growth process coefficients on the complexity indicator increase in absolute value, there seems to be a systematic sorting of less stable firms into more complex products. ${ }^{26}$

\footnotetext{
${ }^{26}$ Our baseline evidence is confirmed when we adopt further alternative volatility calculations (Kalemli-Ozcan et al., 2014): i) log of the standard deviation of discrete growth rates; ii) the log of the absolute value of the coefficient of variation; iii) the log standard deviation of firm growth rates deviation from, respectively, the 2 and 4 digit sector average growth and the log standard deviation of labour productivity. Finally, results are substantially confirmed when we test for lagged - in $t-3-K$ on the log of squared residuals from an AR2 model of firm growth rates. Results are available upon request.
}

It is worth mentioning that results in Tables 4 and 5 are robust if the simple average firm product complexity is replaced by the weighted average of product complexity where the weight of each product is equal to its share in a firm's total exports (see Tables A.5 and A.6 in Appendix A).

In this section, we have modeled and found an empirical robust association between firms' product complexity and their volatility. In particular, we have proved that this result is not affected by sample selection both in terms of export activity and in terms of survival over the 5 -year horizon. Although we are not able to completely rule out the potential endogeneity of product complexity, our results point in the direction of a positive and sizeable impact of complexity on volatility. In the following, we will try to shed light on the drivers of this relationship.

\section{In search for firm-product level drivers of the complexity - volatility nexus}

In this section, we move a step further and inspect the role of product market and technological factors which could drive the negative association between a firm's product complexity and its output volatility.

On one hand, the complexity of a good could reflect different product specific demand and supply conditions. First, more complex goods can enjoy lower demand and substitution elasticities due to their lower ubiquity. We, then, expect their demand to be less affected by external shocks. ${ }^{27}$ We test whether goods' higher complexity is associated to a lower elasticity of substitution/demand and whether this represents a potential mechanism behind the stabilising effect of product complexity for a firm's output growth. In the analysis, then, for each

\footnotetext{
27 Krishna and Levchenko (2013) corroborate this prediction by showing that the elasticity of substitution of sectors is significantly and positively related to their volatility. However, they isolate the impact of the number of required inputs on firms' volatility, by cleansing the effect from the existing differences in demand conditions among sectors.
} 
Table 5

Further robustness checks.

\begin{tabular}{|c|c|c|c|c|c|c|c|c|c|}
\hline & [1] & {$[2]$} & [3] & {$[4]$} & [5] & [6] & [7] & [8] & [9] \\
\hline & \multirow[t]{2}{*}{$\begin{array}{l}\text { Averaged } \\
\text { regressors }^{\mathrm{a}}\end{array}$} & \multirow[t]{2}{*}{ Prody } & \multirow[t]{2}{*}{$\begin{array}{l}\text { Average } \\
\text { growth }\end{array}$} & \multirow[t]{2}{*}{$\begin{array}{l}\text { Region-sector } \\
\text { FEs }\end{array}$} & \multirow[t]{2}{*}{$\begin{array}{l}\log (\text { squared } \\
\text { residual) }\end{array}$} & AR1 & AR2 & \multirow[t]{2}{*}{ AR1 } & \multirow[t]{2}{*}{ AR2 } \\
\hline & & & & & & $\begin{array}{l}\text { Surviving } \\
\text { firms }\end{array}$ & All firms & & \\
\hline$K$ & $\begin{array}{c}-0.060^{* *} \\
{[0.025]}\end{array}$ & $\begin{array}{c}-0.059^{* *} \\
{[0.025]}\end{array}$ & $\begin{array}{c}-0.058^{* * * *} \\
{[0.020]}\end{array}$ & $\begin{array}{c}-0.070^{* * *} \\
{[0.025]}\end{array}$ & $\begin{array}{c}-0.098^{* *} \\
{[0.041]}\end{array}$ & $\begin{array}{c}-0.111^{* *} \\
{[0.048]}\end{array}$ & $\begin{array}{c}-0.134^{* *} \\
{[0.055]}\end{array}$ & $\begin{array}{r}-0.071^{*} \\
{[0.042]}\end{array}$ & $\begin{array}{c}-0.118^{* *} \\
{[0.053]}\end{array}$ \\
\hline Size & $\begin{array}{c}-0.129^{* * *} \\
{[0.013]}\end{array}$ & $\begin{array}{c}-0.115^{* * *} \\
{[0.011]}\end{array}$ & $\begin{array}{c}-0.128^{* * *} \\
{[0.011]}\end{array}$ & $\begin{array}{c}-0.104^{* * *} \\
{[0.014]}\end{array}$ & $\begin{array}{c}-0.238^{* * *} \\
{[0.021]}\end{array}$ & $\begin{array}{c}-0.234^{* * *} \\
{[0.024]}\end{array}$ & $\begin{array}{c}-0.265^{* * *} \\
{[0.028]}\end{array}$ & $\begin{array}{c}-0.235^{* * * *} \\
{[0.021]}\end{array}$ & $\begin{array}{c}-0.240^{* * * *} \\
{[0.026]}\end{array}$ \\
\hline Labour Productivity & $\begin{array}{c}-0.036 \\
{[0.023]}\end{array}$ & $\begin{array}{l}-0.01 \\
{[0.009]}\end{array}$ & $\begin{array}{c}-0.018^{* *} \\
{[0.009]}\end{array}$ & $\begin{array}{c}-0.007 \\
{[0.011]}\end{array}$ & $\begin{array}{c}-0.019 \\
{[0.021]}\end{array}$ & $\begin{array}{c}-0.04 \\
{[0.026]}\end{array}$ & $\begin{array}{c}-0.078^{* *} \\
{[0.032]}\end{array}$ & $\begin{array}{c}-0.084^{* * * *} \\
{[0.023]}\end{array}$ & $\begin{array}{c}-0.099^{* * * *} \\
{[0.032]}\end{array}$ \\
\hline Importer & $\begin{array}{c}-0.123^{* *} \\
{[0.053]}\end{array}$ & $\begin{array}{c}-0.068^{* *} \\
{[0.028]}\end{array}$ & $\begin{array}{c}-0.061^{* *} \\
{[0.028]}\end{array}$ & $\begin{array}{r}-0.066^{*} \\
{[0.035]}\end{array}$ & $\begin{array}{c}-0.209^{* * *} \\
{[0.053]}\end{array}$ & $\begin{array}{c}-0.228^{* * *} \\
{[0.059]}\end{array}$ & $\begin{array}{c}-0.248^{* * *} \\
{[0.072]}\end{array}$ & $\begin{array}{c}-0.184^{* * *} \\
{[0.050]}\end{array}$ & $\begin{array}{c}-0.244^{* * * *} \\
{[0.065]}\end{array}$ \\
\hline Investor Tangibles & $\begin{array}{l}0.019^{* * *} \\
{[0.007]}\end{array}$ & $\begin{array}{c}-0.106^{* * *} \\
{[0.026]}\end{array}$ & $\begin{array}{c}-0.109^{* * * *} \\
{[0.025]}\end{array}$ & $\begin{array}{c}-0.109^{* * *} \\
{[0.032]}\end{array}$ & $\begin{array}{c}-0.189^{* * * *} \\
{[0.048]}\end{array}$ & $\begin{array}{c}-0.194^{* * *} \\
{[0.055]}\end{array}$ & $\begin{array}{c}-0.216^{* * *} \\
{[0.066]}\end{array}$ & $\begin{array}{c}-0.215^{* * * *} \\
{[0.047]}\end{array}$ & $\begin{array}{c}-0.266^{* * * *} \\
{[0.060]}\end{array}$ \\
\hline Investor $^{\text {Intangibles }}$ & $\begin{array}{c}0.811 \\
{[0.862]}\end{array}$ & $\begin{array}{c}0.015 \\
{[0.022]}\end{array}$ & $\begin{array}{c}0.022 \\
{[0.021]}\end{array}$ & $\begin{array}{c}-0.001 \\
{[0.026]}\end{array}$ & $\begin{array}{c}-0.034 \\
{[0.038]}\end{array}$ & $\begin{array}{c}-0.028 \\
{[0.043]}\end{array}$ & $\begin{array}{c}0.028 \\
{[0.050]}\end{array}$ & $\begin{array}{c}-0.035 \\
{[0.037]}\end{array}$ & $\begin{array}{c}0.013 \\
{[0.047]}\end{array}$ \\
\hline Wage & $\begin{array}{r}-0.044 \\
{[0.035]}\end{array}$ & $\begin{array}{c}-0.092^{* * * *} \\
{[0.021]}\end{array}$ & $\begin{array}{c}-0.095^{* * *} \\
{[0.021]}\end{array}$ & $\begin{array}{c}-0.088^{* * *} \\
{[0.026]}\end{array}$ & $\begin{array}{c}-0.180^{* * *} \\
{[0.045]}\end{array}$ & $\begin{array}{c}-0.188^{* * * *} \\
{[0.053]}\end{array}$ & $\begin{array}{c}-0.046 \\
{[0.063]}\end{array}$ & $\begin{array}{c}-0.151^{* * * *} \\
{[0.046]}\end{array}$ & $\begin{array}{r}-0.057 \\
{[0.060]}\end{array}$ \\
\hline Average Growth & & & $\begin{array}{c}-0.766^{* * *} \\
{[0.072]}\end{array}$ & & & & & & \\
\hline Observations & 2663 & 4051 & 4055 & 4055 & 20479 & 16241 & 12190 & 22000 & 14467 \\
\hline $\mathrm{R}$-squared & 0.275 & 0.237 & 0.27 & 0.42 & 0.079 & 0.09 & 0.085 & 0.079 & 0.082 \\
\hline
\end{tabular}

Notes: The dependent variable is the firm output volatility, gvol, in columns [1]-[4], while in columns [5]-[9], the dependent variable is the log of the squared residuals of a growth model with firm and year fixed effects. Robust standard errors in brackets.

All specifications include 4 digit NACE Rev 1.1 sector dummies and NUTS III region fixed effects. Specifications in columns [5]-[9], include also year dummies.

* Significant at $10 \%$ level.

** Significant at $5 \%$ level.

*** Significant at $1 \%$ level.

a In this specification Investor ${ }^{\text {Tangibles }}$ and Investor ${ }^{\text {Intangibles }}$ represent respectively the share of tangible and intangible investments over output averaged over the period.

firm, we measure the average substitution elasticity of its products, $\sigma$, on the basis of the 5 digit SITC level estimates by Broda and Weinstein (2006) for the U.S. economy.

Second, more complex goods are characterised by a higher income elasticity. As a matter of fact, they are presumably consumed by richer countries $^{28}$ - and, within each country, by richer consumers - whose income is less volatile. Hence, we expect that the higher income elasticity and greater demand stability of complex goods is reflected in higher consumption shares of richer countries in these products and a lower income volatility of the typical consumers. Then, we test whether these could be two further relevant demand side drivers of the complexity - volatility nexus at the firm level. Product demand income elasticity is proxied by the consumption share of high income economies averaged across firms' export products, Consumption ${ }^{\text {High Income }}$. The basic idea is that the extent of high income economies' preference for a particular product should be revealed by the product's weight in their total consumption. As detailed product level data on high income economies' total consumption are not available, we rely on their product level imports. By the same token, as we cannot observe countries' total consumption of a good, in order to measure the average demand volatility faced by a firm with a certain export basket, Volatility ${ }^{\text {Demand }}$, we hinge on the per capita income volatility averaged across a product's importers.

Third, turning to the product market supply side, entry into production of complex goods could entail higher fixed and sunk costs. Entry barriers reduce the extent of competition and, hence, increase market concentration. For this reason, firms involved in these productions could enjoy higher stability. ${ }^{29}$ Market concentration and/or level of entry barriers at the product level, Concentration ${ }^{\text {Supply }}$, are proxied by

\footnotetext{
${ }^{28}$ Extant literature, indeed, shows that richer economies tend to consume better-higher quality goods (Hallak, 2006).

29 In this respect, Irvine and Pontiff (2009) find that increased competition, driven by both the entry of foreign firms and deregulation processes, is one of the main sources at the basis of the rise in idiosyncratic volatility over the period 1964-2003.
}

the average product market Herfindahl index across exporters of the goods exported by the firm (Fernandes et al., 2016).

On the other hand, the stabilising role of product complexity could be driven by the technological characteristics of complex goods. Two are the main origins of product complexity envisaged by the literature which could bear a stabilising effect. Complex goods entail the use of a large variety of inputs. The notion of product complexity we adopt in this paper builds on the idea that complex goods originate from the combination of numerous and diversified capabilities. Our indicator could, therefore, reflect the extent of technological diversification of products as represented by the number of inputs required. Firms' complexity would, then, stabilise their turnover, due to a minor impact of an input - specific shock on the production outcome (Krishna and Levchenko, 2013; Koren and Tenreyro, 2013). Nonetheless, considering only the number of inputs required in production partially neglects the fundamental role of knowledge in complex productions. In particular, although a higher number of inputs in production generally entails a higher ability and technological knowledge to coordinate the production process (Becker and Murphy, 1992), it could not entirely reflect the human capital content of products. As people specialise in a small set of skills and the number of tasks increases, task specific human capital and general knowledge grow. If higher task specific human capital reflects higher learning abilities, a higher skill intensity of products could indeed be a source of stability per se. ${ }^{30}$ In order to capture both aspects of the technological features of complex products, we will then explore the relationship between a firm's volatility and both the implicit technological diversification and human capital content of its export basket. The average number of inputs, $N^{\text {Input }}$, is measured as the log average of the number of inputs required by the production process of each of the goods produced by a firm. The average human capital intensity of products, instead, rests on their standardised index of Revealed Human Capital Intensity (Shirotori et al., 2010).

\footnotetext{
30 From the model proposed by Krishna and Levchenko (2013), it can easily been shown that a higher complexity index is referable both to products with higher human capital and higher technological diversification.
} 
Table 6

Complexity Drivers.

\begin{tabular}{|c|c|c|c|c|c|c|c|c|c|}
\hline & [1] & {$[2]$} & [3] & {$[4]$} & [5] & [6] & [7] & [8] & [9] \\
\hline & \multicolumn{4}{|c|}{ Product market conditions } & \multicolumn{2}{|c|}{ Technological factors } & \multicolumn{3}{|l|}{ Both } \\
\hline 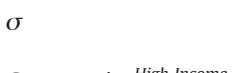 & $\begin{array}{l}-0.171^{* * *} \\
{[0.029]}\end{array}$ & & & & & & $\begin{array}{l}-0.023^{*} \\
{[0.014]}\end{array}$ & $\begin{array}{l}0.026(0.014) \\
{[0.017]}\end{array}$ & $\begin{array}{l}0.021(0.011) \\
{[0.017]}\end{array}$ \\
\hline Consumption ${ }^{\text {High Income }}$ & & $\begin{array}{l}119.097^{* * *} \\
{[14.669]}\end{array}$ & & & & & $\begin{array}{l}48.547^{* * *} \\
{[8.086]}\end{array}$ & $\begin{array}{l}16.84^{* * *}(0.018) \\
{[5.475]}\end{array}$ & $\begin{array}{l}18.18^{* * *}(0.019) \\
{[5.506]}\end{array}$ \\
\hline$V_{\text {Volatility }}^{\text {Demand }}$ & & & $\begin{array}{l}-2.704^{* * *} \\
{[0.253]}\end{array}$ & & & & $\begin{array}{l}-0.496^{* * * *} \\
{[0.131]}\end{array}$ & $\begin{array}{l}-0.0972(-0.006) \\
{[0.209]}\end{array}$ & $\begin{array}{l}-0.0925(-0.005) \\
{[0.218]}\end{array}$ \\
\hline Concentration $^{\text {Supply }}$ & & & & $\begin{array}{l}2.673^{* * *} \\
{[0.137]}\end{array}$ & & & $\begin{array}{l}1.331^{* * *} \\
{[0.082]}\end{array}$ & $\begin{array}{l}0.704^{* * *}(0.076) \\
{[0.092]}\end{array}$ & $\begin{array}{l}\left.0.693^{* * *}(0.074)\right] \\
{[0.092]}\end{array}$ \\
\hline$N^{\text {Input }}$ & & & & & $\begin{array}{l}6.902^{* * * *} \\
{[0.199]}\end{array}$ & & $\begin{array}{l}1.949^{* * *} \\
{[0.109]}\end{array}$ & $\begin{array}{l}1.918^{* * *}(0.159) \\
{[0.154]}\end{array}$ & $\begin{array}{l}1.918^{* * * *}(0.158) \\
{[0.154]}\end{array}$ \\
\hline Human Capital ${ }^{\text {Intensity }}$ & & & & & & $\begin{array}{l}1.091^{* * *} \\
{[0.016]}\end{array}$ & $\begin{array}{l}0.953^{* * *} \\
{[0.011]}\end{array}$ & $\begin{array}{l}0.679^{* * *}(0.530) \\
{[0.020]}\end{array}$ & $\begin{array}{l}0.664^{* * * *}(0.519) \\
{[0.020]}\end{array}$ \\
\hline Size & & & & & & & & & $\begin{array}{l}0.020^{* * *}(0.023) \\
{[0.006]}\end{array}$ \\
\hline Labour Productivity & & & & & & & & & $\begin{array}{l}0.008(0.0100) \\
{[0.005]}\end{array}$ \\
\hline Importer & & & & & & & & & $\begin{array}{l}0.045^{* * * *}(0.0185) \\
{[0.015]}\end{array}$ \\
\hline Investor Tangibles & & & & & & & & & $\begin{array}{l}0.007(0.003) \\
{[0.014]}\end{array}$ \\
\hline Investor Intangibles & & & & & & & & & $\begin{array}{l}0.006(0.003) \\
{[0.012]}\end{array}$ \\
\hline Wage & & & & & & & & & $\begin{array}{l}0.039^{* * *}(0.025) \\
{[0.012]}\end{array}$ \\
\hline Observations & 4067 & 4174 & 4174 & 4146 & 4174 & 4173 & 3926 & 4042 & 3926 \\
\hline R-squared & 0.009 & 0.016 & 0.027 & 0.084 & 0.334 & 0.736 & 0.79 & 0.891 & 0.894 \\
\hline Sector & no & no & no & no & no & no & no & yes & yes \\
\hline Region & no & no & no & no & no & no & no & yes & yes \\
\hline
\end{tabular}

Notes: The dependent variable is the firm product complexity, $K .{ }^{*}$ Significant at $10 \%$ level; ${ }^{* *}$ significant at $5 \%$ level; ${ }^{* * *}$ significant at $1 \%$ level. Robust standard errors in brackets. All specifications that indicate the inclusion of sector and region fixed effects contain 4 digit NACE Rev 1.1 sector dummies and NUTS III region dummies. In columns [8]-[9] standardised coefficients are shown in parenthesis.

Table A.7 in the Appendix A includes a detailed description of all the computations and data sources used to build the measures associated to potential drivers which are all measured in year 2002. The relationship between the latter and our complexity indicator is summarized in Table 6 where we present the OLS estimates of a simple model for firm product complexity where the above indicators are first included one by one and then all together, both without and with region and sector fixed effects. From the Table we can assess that each indicator shows a significant correlation with firm product complexity and they all present the expected sign (columns [1] to [7]). Nevertheless, when in column [8] we account for region and sector fixed effects, $\sigma$ looses its significance and the same happens for Volatility ${ }^{\text {Demand }}$ when we further add firm controls in column [9]. Both columns [8] and [9] present standardised coefficients in parenthesis and indicate that variation of technological factors explains more of firm product complexity than product specific market conditions. Among the latter, though, the highest importance can be attributed to market concentration.

Turning to the relationship between volatility and the above indicators, columns[1]-[5] of Table 7 inspect the role of product market conditions whereas columns [6]-[10] inspect the role of technological factors.

When variables capturing product specific market conditions are included with no additional control we find that, with the exception of $\sigma$, all factors are significant and show the expected sign. In particular, a higher share of consumption by rich economies and a higher market concentration are negatively associated to firm volatility, while a higher volatility of per capita income of consumer countries goes with an increase of volatility. When we include firm level controls in column [2] high income countries' consumption share looses its significance and a mild significant and positive coefficient appears on $\sigma$. When in column [3] complexity is added to the specification, we find that the latter absorbs the significance of all the product market characteristics and this suggests that, across firms, product complexity mediates the positive role of more stable demand and supply conditions. Nonetheless, when we control for region and sector fixed effects in columns [4]-[5], firm output volatility is only significantly affected by product level demand volatility and this effect does not appear to be related to the stabilising role of complexity since the coefficient associated to Volatility Demand preserves its significance and size.

This suggest that across similar firms active in the same narrowly defined locations and sectors the effect of product complexity is not reflecting product market conditions.

Turning to the role of technological factors, in the absence of any other control, both $N^{\text {Input }}$ and Human Capital ${ }^{\text {Intensity }}$ appear to be negatively associated with a firm's volatility in column [6]. When we include firm level controls, only the significance of the product skill content persists (column [7]). Nonetheless, it vanishes when in column (Fernandes et al., 2016) we add complexity to the specification. This pattern is confirmed with the inclusion of region and sector fixed effects in columns [9]-[10]. Therefore, across firms higher product complexity also entails higher technological diversification and higher human capital content of products. Results, though, imply that the former is less of a source of heterogeneity across similar firms than the latter. It is likely that sector characteristics captured by the inclusion of a high number of sector fixed effects absorb heterogeneity across firms in terms of the number of inputs.

The above findings are corroborated when market and technological factors are tested together in columns [11]-[12]. Here standardised coefficients, that are shown in parenthesis, indicate that within region and sectors our complexity indicator is fully capturing the role of human capital and this corresponds to most of its effect.

The evidence emerging from Tables 6 and 7 suggests two main conclusions: i) across similar firms active in different sectors and locations the negative and significant relationship between product complexity and volatility reflects both product specific market and technological factors; ii) when sector and region characteristics are accounted for, the negative and significant relationship between product complexity and volatility fuels a higher skill intensity of complex products and, in this sense, if a causal interpretation could be attributed to our findings, 
Table 7

The Role of Product Market Conditions and Technological Factors.

\begin{tabular}{|c|c|c|c|c|c|c|c|c|c|c|c|c|}
\hline & $\underline{[1]}$ & [2] & {$[3]$} & {$[4]$} & {$[5]$} & [6] & [7] & [8] & [9] & [10] & [11] & [12] \\
\hline & \multicolumn{5}{|c|}{ Product Market Conditions } & \multicolumn{5}{|c|}{ Technological Factors } & \multicolumn{2}{|l|}{ Both } \\
\hline$\sigma$ & $\begin{array}{l}0.008 \\
{[0.020]}\end{array}$ & $\begin{array}{l}0.036^{*} \\
{[0.020]}\end{array}$ & $\begin{array}{l}0.015 \\
{[0.020]}\end{array}$ & $\begin{array}{l}0.009 \\
{[0.023]}\end{array}$ & $\begin{array}{l}0.011 \\
{[0.023]}\end{array}$ & & & & & & $\begin{array}{l}0.009(0.007) \\
{[0.023]}\end{array}$ & $\begin{array}{l}0.011(0.008) \\
{[0.023]}\end{array}$ \\
\hline Consumption ${ }^{\text {High Income }}$ & $\begin{array}{l}-27.063^{* * *} \\
{[10.136]}\end{array}$ & $\begin{array}{l}-10.69 \\
{[10.450]}\end{array}$ & $\begin{array}{l}13.6 \\
{[11.622]}\end{array}$ & $\begin{array}{l}7.76 \\
{[12.782]}\end{array}$ & $\begin{array}{l}12.16 \\
{[13.023]}\end{array}$ & & & & & & $\begin{array}{l}10.15(0.015) \\
{[13.060]}\end{array}$ & $\begin{array}{l}11.24(0.017) \\
{[13.052]}\end{array}$ \\
\hline Volatility ${ }^{\text {Demand }}$ & $\begin{array}{l}0.494^{* * * *} \\
{[0.177]}\end{array}$ & $\begin{array}{l}0.465^{* * *} \\
{[0.177]}\end{array}$ & $\begin{array}{l}0.258 \\
{[0.177]}\end{array}$ & $\begin{array}{l}0.407^{* *} \\
{[0.196]}\end{array}$ & $\begin{array}{l}0.398^{* * *} \\
{[0.195]}\end{array}$ & & & & & & $\begin{array}{l}0.401^{* *}(0.033) \\
{[0.196]}\end{array}$ & $\begin{array}{l}0.395^{* *}(0.032) \\
{[0.195]}\end{array}$ \\
\hline Concentration $^{\text {Supply }}$ & $\begin{array}{l}-0.618^{* * *} \\
{[0.109]}\end{array}$ & $\begin{array}{l}-0.306^{* * *} \\
{[0.109]}\end{array}$ & $\begin{array}{l}0.048 \\
{[0.116]}\end{array}$ & $\begin{array}{l}-0.078 \\
{[0.137]}\end{array}$ & $\begin{array}{l}0.008 \\
{[0.138]}\end{array}$ & & & & & & $\begin{array}{l}-0.053(-0.008) \\
{[0.140]}\end{array}$ & $\begin{array}{l}-0.012(-0.002) \\
{[0.140]}\end{array}$ \\
\hline K & & & $\begin{array}{l}-0.099^{* * *} \\
{[0.012]}\end{array}$ & & $\begin{array}{l}-0.065^{* * *} \\
{[0.021]}\end{array}$ & & & $\begin{array}{l}-0.117^{* * *} \\
{[0.022]}\end{array}$ & & $\begin{array}{l}-0.059^{* *} \\
{[0.030]}\end{array}$ & & $\begin{array}{l}-0.060^{* *}(-0.087) \\
{[0.030]}\end{array}$ \\
\hline$N^{\text {Input }}$ & & & & & & $\begin{array}{l}-0.311^{* *} \\
{[0.144]}\end{array}$ & $\begin{array}{l}-0.224 \\
{[0.144]}\end{array}$ & $\begin{array}{l}0.0713 \\
{[0.155]}\end{array}$ & $\begin{array}{l}-0.005 \\
{[0.198]}\end{array}$ & $\begin{array}{l}0.118 \\
{[0.207]}\end{array}$ & $\begin{array}{l}-0.002(0.00002) \\
{[0.211]}\end{array}$ & $\begin{array}{l}0.113(0.014) \\
{[0.220]}\end{array}$ \\
\hline Human Capital Intensity & & & & & & $\begin{array}{l}-0.101^{* * * *} \\
{[0.015]}\end{array}$ & $\begin{array}{l}-0.0887^{* * *} \\
{[0.015]}\end{array}$ & $\begin{array}{l}0.0203 \\
{[0.026]}\end{array}$ & $\begin{array}{l}-0.053^{* *} \\
{[0.021]}\end{array}$ & $\begin{array}{l}-0.014 \\
{[0.028]}\end{array}$ & 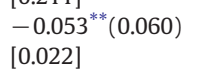 & $\begin{array}{l}-0.013(-0.015) \\
{[0.030]}\end{array}$ \\
\hline Size & & $\begin{array}{l}-0.080^{* * *} \\
{[0.011]}\end{array}$ & $\begin{array}{l}-0.093^{* * *} \\
{[0.011]}\end{array}$ & $\begin{array}{l}-0.112^{* *} \\
{[0.011]}\end{array}$ & $\begin{array}{l}-0.110^{* *} \\
{[0.011]}\end{array}$ & & $\begin{array}{l}-0.0952^{* * *} \\
{[0.010]}\end{array}$ & $\begin{array}{l}-0.0984^{* * *} \\
{[0.010]}\end{array}$ & $\begin{array}{l}-0.114^{* * *} \\
{[0.011]}\end{array}$ & $\begin{array}{l}-0.113^{* * *} \\
{[0.011]}\end{array}$ & $\begin{array}{l}-0.111^{* * *}(0.185) \\
{[0.011]}\end{array}$ & $\begin{array}{l}-0.110^{* * *}(-0.183) \\
{[0.011]}\end{array}$ \\
\hline Labour Productivity & & $\begin{array}{l}-0.009 \\
{[0.009]}\end{array}$ & $\begin{array}{l}-0.009 \\
{[0.009]}\end{array}$ & $\begin{array}{l}-0.014 \\
{[0.009]}\end{array}$ & $\begin{array}{l}-0.013 \\
{[0.009]}\end{array}$ & & $\begin{array}{l}-0.00548 \\
{[0.009]}\end{array}$ & $\begin{array}{l}-0.0039 \\
{[0.009]}\end{array}$ & $\begin{array}{l}-0.011 \\
{[0.009]}\end{array}$ & $\begin{array}{l}-0.011 \\
{[0.009]}\end{array}$ & $\begin{array}{l}-0.0136(-0.025) \\
{[0.009]}\end{array}$ & $\begin{array}{l}-0.013(-0.024) \\
{[0.009]}\end{array}$ \\
\hline Importer & & $\begin{array}{l}-0.084^{* * *} \\
{[0.028]}\end{array}$ & $\begin{array}{l}-0.076^{* * *} \\
{[0.028]}\end{array}$ & $\begin{array}{l}-0.067^{* *} \\
{[0.029]}\end{array}$ & $\begin{array}{l}-0.062^{* *} \\
{[0.029]}\end{array}$ & & $\begin{array}{l}-0.0778^{* * *} \\
{[0.027]}\end{array}$ & $\begin{array}{l}-0.0685^{* *} \\
{[0.027]}\end{array}$ & $\begin{array}{l}-0.066^{* *} \\
{[0.028]}\end{array}$ & $\begin{array}{l}-0.063^{* *} \\
{[0.028]}\end{array}$ & $\begin{array}{l}-0.065^{* *}(-0.039) \\
{[0.029]}\end{array}$ & $\begin{array}{l}-0.063^{* *}(-0.037) \\
{[0.029]}\end{array}$ \\
\hline Investor Tangibles & & $\begin{array}{l}-0.121^{* * *} \\
{[0.027]}\end{array}$ & $\begin{array}{l}-0.120^{* * * *} \\
{[0.026]}\end{array}$ & $\begin{array}{l}-0.104^{* * *} \\
{[0.027]}\end{array}$ & $\begin{array}{l}-0.104^{* * *} \\
{[0.027]}\end{array}$ & & $\begin{array}{l}-0.125^{* * *} \\
{[0.026]}\end{array}$ & $\begin{array}{l}-0.124^{* * *} \\
{[0.026]}\end{array}$ & $\begin{array}{l}-0.111^{* * *} \\
{[0.026]}\end{array}$ & $\begin{array}{l}-0.111^{* * *} \\
{[0.026]}\end{array}$ & $\begin{array}{l}-0.105^{* * *}(-0.066) \\
{[0.027]}\end{array}$ & $\begin{array}{l}-0.104^{* * *}(-0.066) \\
{[0.027]}\end{array}$ \\
\hline Investor ${ }^{\text {Intangibles }}$ & & $\begin{array}{l}0.007 \\
{[0.022]}\end{array}$ & $\begin{array}{l}0.012 \\
{[0.022]}\end{array}$ & $\begin{array}{l}0.019 \\
{[0.022]}\end{array}$ & $\begin{array}{l}0.019 \\
{[0.022]}\end{array}$ & & $\begin{array}{l}0.006 \\
{[0.022]}\end{array}$ & $\begin{array}{l}0.008 \\
{[0.022]}\end{array}$ & $\begin{array}{l}0.015 \\
{[0.022]}\end{array}$ & $\begin{array}{l}0.015 \\
{[0.022]}\end{array}$ & $\begin{array}{l}0.018(0.014) \\
{[0.022]}\end{array}$ & $\begin{array}{l}0.018(0.014) \\
{[0.022]}\end{array}$ \\
\hline Wage & & $\begin{array}{l}-0.136^{* * *} \\
{[0.020]}\end{array}$ & $\begin{array}{l}-0.099^{* * *} \\
{[0.021]}\end{array}$ & $\begin{array}{l}-0.093^{* * *} \\
{[0.022]}\end{array}$ & $\begin{array}{l}-0.089^{* * *} \\
{[0.022]}\end{array}$ & & $\begin{array}{l}-0.111^{* * *} \\
{[0.020]}\end{array}$ & $\begin{array}{l}-0.096^{* * * *} \\
{[0.020]}\end{array}$ & $\begin{array}{l}-0.090^{* * * *} \\
{[0.021]}\end{array}$ & $\begin{array}{l}-0.088^{* * *} \\
{[0.021]}\end{array}$ & $\begin{array}{l}-0.091^{* * *}(0.087) \\
{[0.022]}\end{array}$ & 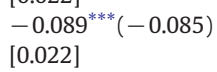 \\
\hline Observations & 4042 & 3926 & 3926 & 3926 & 3926 & 4173 & 4054 & 4054 & 4054 & 4054 & 3926 & 3926 \\
\hline $\begin{array}{l}\mathrm{R}-\text { squared } \\
\mathrm{FE}\end{array}$ & 0.01 & 0.079 & 0.094 & 0.232 & 0.234 & 0.021 & 0.09 & 0.097 & 0.238 & 0.239 & 0.233 & 0.234 \\
\hline Sector & No & No & No & Yes & Yes & No & No & No & Yes & Yes & Yes & Yes \\
\hline Region & No & No & No & Yes & Yes & No & No & No & Yes & Yes & Yes & Yes \\
\hline
\end{tabular}

Notes: The dependent variable is the firm output volatility, gvol. Robust standard errors in brackets.

All specifications that, at the bottom of the Table, indicate the inclusion of sector and region fixed effects contain 4 digit NACE Rev 1.1 sector dummies and NUTS III region dummies

In columns [11]-[12] standardised coefficients are shown in parenthesis.

In columns $[11]-[12]$ standaricant
$*$ Significant at $10 \%$ level.

*** Significant at $1 \%$ level. 
one could conclude that our measure of product complexity mediates the positive impact of the human capital content of a firm's product mix on growth stability.

Findings in our work, then, are in line with the existing literature showing that product complexity drives to a reduction of volatility. Differently from previous analysis, though, we find that the complexity - volatility nexus is not only significant across sectors, but it is also relevant across firms active in narrowly defined sectors. Within sectors, indeed, we show that firms producing higher complex goods are less volatile and this evidence reflects the positive association between human capital and product complexity, rather than the positive nexus between the latter and firms' technological diversification.

\section{Conclusions}

With this work we have contributed to empirical literature on the role of countries' specialisation for their economic growth path stability. By using firm level data on Turkish manufacturing sector we have shown, for the first time to our knowledge, that firms' higher product complexity is associated to a reduction in their volatility. The potential consequences of product complexity for an economy can be sizeable. This finding is robust to several sensitivity checks and to the control for sample selection. By measuring product complexity according to the Hausmann and Hidalgo's (2009) indicator we further have enlarged the scope of possible factors which could explain the stabilising role of specialisation in more complex goods. Beyond the importance of technological diversification explored by the literature (Koren and Tenreyro, 2013; Krishna and Levchenko, 2013), the human capital content of firms' product baskets, their lower demand elasticity and volatility and higher entry barriers play a role in driving the effect of complexity on volatility across similar firms active in different sectors. Nonetheless, within narrowly defined sectors and locations, the complexity-volatility nexus fully captures and almost totally reflects the contribution of the human capital content of firms' product basket.

Two main insights emerge from our work. First, product complexity is a further important dimension of heterogeneity across firms with very similar relevant observable characteristics. More specifically, our evidence shows that such heterogeneity matters for the stability of firms sharing the same institutional framework and all having access to the same production factors. Second, as firm product complexity could importantly affect a country's overall economic growth performance, our evidence suggests that micro policies for growth could be relevant. In particular, beyond education policies directed to the enhancement of the extent of general knowledge, countries should favour the accumulation of product - specific knowledge for the realisation of more complex goods.

Future research should be devoted to delving further into the notion of firm complexity. In particular, the most important goal would be to map firms' capabilities into their product baskets. The availability of linked employer - employee database would allow to measure and identify firms' capabilities on the bases of their workforce's skills and competencies. Then, one could verify if more complex firms are less volatile due to their wider range of knowledge intensive capabilities which can be combined in highly diversified productions and, then, allow a higher flexibility and ability to easily adjust to external shocks.

\section{Acknowledgements}

Financial support from the EU 7th FP project RASTANEWS, grant no 320278 is gratefully acknowledged. We thank Jože Damijan, Francesco di Comite, Philipp Marek, Christian Volpe Martincus and all participants to the 11th Annual FREIT-LETC Conference for useful comments and suggestions. The data used in this work are from the Foreign Trada Data, the Annual Business Statistics and the Production Surveys provided by Turkish Statistical Office (TurkStat). All elaborations have been conducted at the Microdata Research Centre of TurkStat under the respect of the law on the statistic secret and the personal data protection. The results and the opinions expressed in this article are exclusive responsibility of the Authors and, by no means, represent official statistics. We are grateful to Bülent Tungul, Mahmut Öztürk, Kenan Orhan and Erdal Yildirim from TurkStat for their help with foreign trade data. We also thank Vedat Metin, Ülkü Ünsal and Oğuzhan Türkoğlu from dissemination department.

\section{Appendix A. Additional figures and tables}

Table A.1

Distribution of sample firms by sector.

\begin{tabular}{|c|c|c|c|}
\hline Sector & Freq. & Percent & Cum. \\
\hline 15 & 308 & 7.38 & 7.38 \\
\hline 17 & 660 & 15.81 & 23.19 \\
\hline 18 & 569 & 13.63 & 36.82 \\
\hline 19 & 106 & 2.54 & 39.36 \\
\hline 20 & 52 & 1.25 & 40.61 \\
\hline 21 & 112 & 2.68 & 43.29 \\
\hline 22 & 61 & 1.46 & 44.75 \\
\hline 24 & 178 & 4.26 & 49.02 \\
\hline 25 & 266 & 6.37 & 55.39 \\
\hline 26 & 221 & 5.29 & 60.69 \\
\hline 27 & 177 & 4.24 & 64.93 \\
\hline 28 & 268 & 6.42 & 71.35 \\
\hline 29 & 444 & 10.64 & 81.98 \\
\hline 30 & 3 & 0.07 & 82.06 \\
\hline 31 & 149 & 3.57 & 85.63 \\
\hline 32 & 36 & 0.86 & 86.49 \\
\hline 33 & 44 & 1.05 & 87.54 \\
\hline 34 & 202 & 4.84 & 92.38 \\
\hline 35 & 33 & 0.79 & 93.17 \\
\hline 36 & 285 & 6.83 & 100 \\
\hline Total & 4174 & 100 & \\
\hline
\end{tabular}

Notes: Source: TurkStat SBS and FTS. Own calculations. 
Table A.2

Distribution of sample firms by NUTS 2 regions.

\begin{tabular}{|c|c|c|c|}
\hline NUTS 2 region & Freq. & Percent & Cum. \\
\hline Istanbul & 2020 & 48.39 & 48.39 \\
\hline Tekirdag & 59 & 1.41 & 49.81 \\
\hline Balikesir & 47 & 1.13 & 50.93 \\
\hline Izmir & 398 & 9.54 & 60.47 \\
\hline Aydin & 103 & 2.47 & 62.94 \\
\hline Manisa & 113 & 2.71 & 65.64 \\
\hline Bursa & 410 & 9.82 & 75.47 \\
\hline Kocaeli & 213 & 5.1 & 80.57 \\
\hline Ankara & 222 & 5.32 & 85.89 \\
\hline Konya & 103 & 2.47 & 88.36 \\
\hline Antalya & 34 & 0.81 & 89.17 \\
\hline Adana & 86 & 2.06 & 91.23 \\
\hline Hatay & 51 & 1.22 & 92.45 \\
\hline Kirikkale & 15 & 0.36 & 92.81 \\
\hline Kayseri & 96 & 2.3 & 95.11 \\
\hline Zonguldak & 20 & 0.48 & 95.59 \\
\hline Kastamonu & 9 & 0.22 & 95.81 \\
\hline Samsun & 44 & 1.05 & 96.86 \\
\hline Trabzon & 34 & 0.81 & 97.68 \\
\hline A1-Erzurum & 1 & 0.02 & 97.7 \\
\hline A2-Agri & 1 & 0.02 & 97.72 \\
\hline B1-Malatya & 15 & 0.36 & 98.08 \\
\hline C1-Gaziantep & 75 & 1.8 & 99.88 \\
\hline C2-Sanliurfa & 4 & 0.1 & 99.98 \\
\hline C3-Mardin & 1 & 0.02 & 100 \\
\hline Total & 4174 & 100 & \\
\hline
\end{tabular}

Notes: Source: TurkStat SBS and FTS. Own calculations.

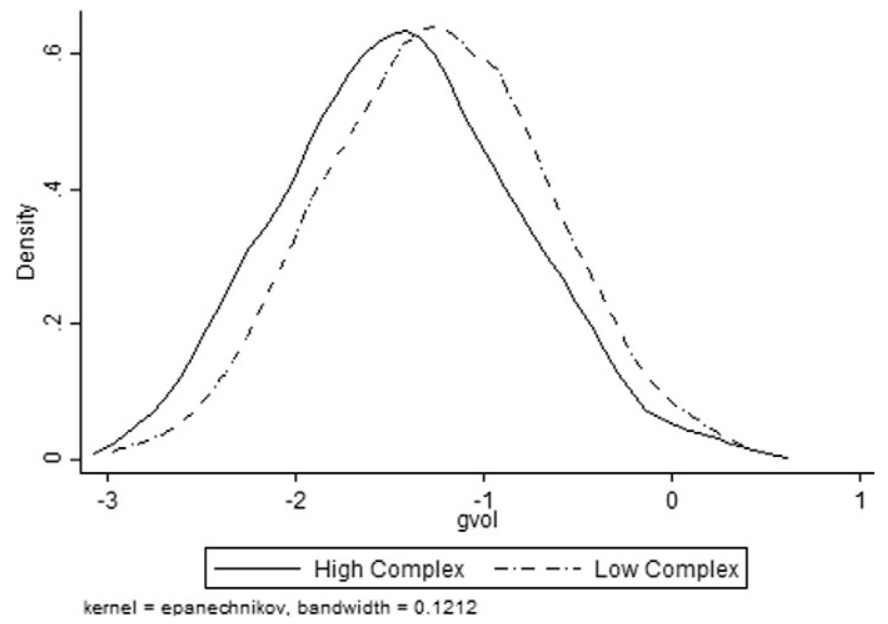

Fig. A.1. Observed firm volatility by export complexity levels. Source: TurkStat SBS and FTS. Own calculations.

Table A.3

Firm growth, volatility and complexity.

\begin{tabular}{|c|c|c|c|c|c|c|}
\hline \multirow[b]{2}{*}{$K$} & \multicolumn{3}{|c|}{ Firm average growth rate $2008 / 2004$} & \multicolumn{3}{|c|}{ Firm median growth rate $2008 / 2004$} \\
\hline & $\begin{array}{l}0.014^{* *} \\
{[0.005]}\end{array}$ & & $\begin{array}{l}0.010^{*} \\
{[0.005]}\end{array}$ & $\begin{array}{l}0.015^{* *} \\
{[0.006]}\end{array}$ & & $\begin{array}{l}0.011^{*} \\
{[0.006]}\end{array}$ \\
\hline gvol & & $\begin{array}{l}-0.058^{* * *} \\
{[0.006]}\end{array}$ & $\begin{array}{l}-0.058^{* * *} \\
{[0.006]}\end{array}$ & & $\begin{array}{l}-0.050^{* * *} \\
{[0.005]}\end{array}$ & $\begin{array}{l}-0.050^{* * *} \\
{[0.005]}\end{array}$ \\
\hline Output $_{2003}$ & $\begin{array}{l}-0.024^{* * *} \\
{[0.002]}\end{array}$ & $\begin{array}{l}-0.031^{* * * *} \\
{[0.002]}\end{array}$ & $\begin{array}{l}-0.031^{\text {**** }} \\
{[0.002]}\end{array}$ & $\begin{array}{l}-0.017^{* * * *} \\
{[0.002]}\end{array}$ & $\begin{array}{l}-0.022^{* * *} \\
{[0.002]}\end{array}$ & $\begin{array}{l}-0.023^{* * *} \\
{[0.002]}\end{array}$ \\
\hline Constant & $\begin{array}{l}0.478^{* * *} \\
{[0.065]}\end{array}$ & $\begin{array}{l}0.516^{* * *} \\
{[0.066]}\end{array}$ & $\begin{array}{l}0.526^{* * *} \\
{[0.066]}\end{array}$ & $\begin{array}{l}0.399^{* * *} \\
{[0.080]}\end{array}$ & $\begin{array}{l}0.430^{* * *} \\
{[0.080]}\end{array}$ & $\begin{array}{l}0.440^{* * *} \\
{[0.080]}\end{array}$ \\
\hline Observations & 4174 & 4174 & 4174 & 4174 & 4174 & 4174 \\
\hline $\mathrm{R}$ - squared & 0.214 & 0.251 & 0.252 & 0.167 & 0.191 & 0.192 \\
\hline
\end{tabular}

Robust standard errors in brackets.

All specifications include 4 digit NACE Rev 1.1 sector and NUTS III region dummies.

* Significant at $10 \%$ level.

** Significant at 5\% level.

*** Significant at $1 \%$ level. 


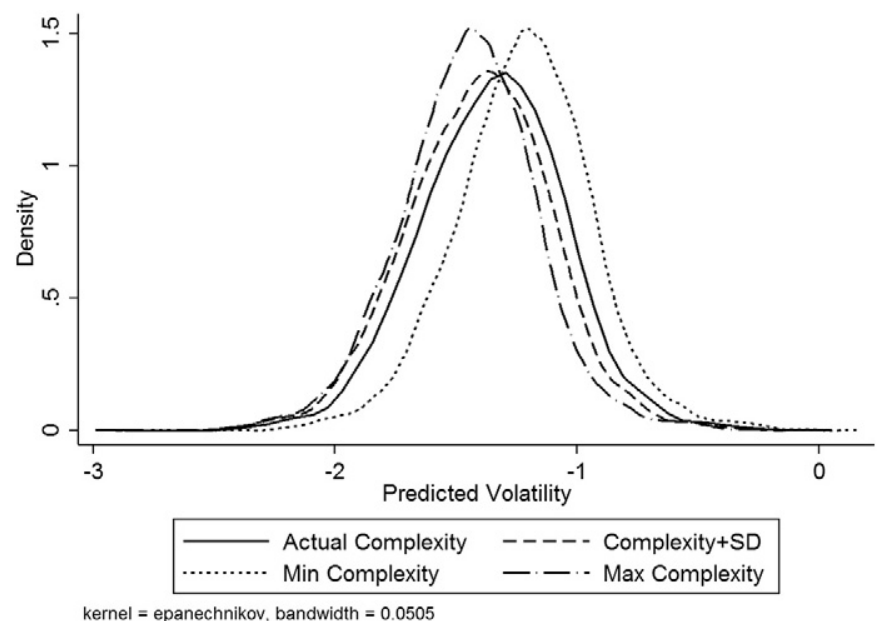

Fig. A.2. Actual and predicted volatility - different counterfactual. Source: TurkStat SBS and FTS. Own calculations.

Table A.4

Firm output volatility and product complexity 2006/2008: AIPS production data.*

\begin{tabular}{|c|c|c|c|c|c|c|}
\hline & [1] & [2] & [3] & {$[4]$} & [5] & [6] \\
\hline$K$ & $\begin{array}{l}-0.066^{* * *} \\
{[0.018]}\end{array}$ & $\begin{array}{l}-0.070^{* * *} \\
{[0.018]}\end{array}$ & $\begin{array}{l}-0.064^{* * * *} \\
{[0.018]}\end{array}$ & $\begin{array}{l}-0.062^{* * *} \\
{[0.018]}\end{array}$ & $\begin{array}{l}-0.064^{* * *} \\
{[0.018]}\end{array}$ & $\begin{array}{l}-0.063^{* * *} \\
{[0.018]}\end{array}$ \\
\hline Size & & $\begin{array}{l}-0.169^{* * *} \\
{[0.008]}\end{array}$ & $\begin{array}{l}-0.128^{* * *} \\
{[0.010]}\end{array}$ & $\begin{array}{l}-0.128^{* * *} \\
{[0.010]}\end{array}$ & $\begin{array}{l}-0.128^{* * *} \\
{[0.010]}\end{array}$ & $\begin{array}{l}-0.128^{* * *} \\
{[0.010]}\end{array}$ \\
\hline Labour Productivity & & & $\begin{array}{l}-0.051^{* * *} \\
{[0.010]}\end{array}$ & $\begin{array}{l}-0.050^{* * *} \\
{[0.010]}\end{array}$ & $\begin{array}{l}-0.051^{* * *} \\
{[0.010]}\end{array}$ & $\begin{array}{l}-0.050^{* * *} \\
{[0.010]}\end{array}$ \\
\hline Importer & & & $\begin{array}{l}-0.062^{* * *} \\
{[0.019]}\end{array}$ & $\begin{array}{l}-0.062^{* * *} \\
{[0.019]}\end{array}$ & $\begin{array}{l}-0.063^{* * *} \\
{[0.019]}\end{array}$ & $\begin{array}{l}-0.062^{\text {*** }} \\
{[0.019]}\end{array}$ \\
\hline Investor ${ }^{\text {Tangibles }}$ & & & $\begin{array}{l}-0.079^{* * *} \\
{[0.019]}\end{array}$ & $\begin{array}{l}-0.079^{* * *} \\
{[0.019]}\end{array}$ & $\begin{array}{l}-0.079^{* * *} \\
{[0.019]}\end{array}$ & $\begin{array}{l}-0.080^{* * * *} \\
{[0.019]}\end{array}$ \\
\hline Investor $^{\text {Intangibles }}$ & & & $\begin{array}{l}-0.041^{* *} \\
{[0.019]}\end{array}$ & $\begin{array}{l}-0.041^{* *} \\
{[0.019]}\end{array}$ & $\begin{array}{l}-0.041^{* *} \\
{[0.019]}\end{array}$ & $\begin{array}{l}-0.041^{* *} \\
{[0.019]}\end{array}$ \\
\hline Wage & & & $\begin{array}{l}-0.084^{* * *} \\
{[0.020]}\end{array}$ & $\begin{array}{l}-0.084^{* * *} \\
{[0.020]}\end{array}$ & $\begin{array}{l}-0.084^{* * *} \\
{[0.020]}\end{array}$ & $\begin{array}{l}-0.084^{* * *} \\
{[0.020]}\end{array}$ \\
\hline Export Share & & & $\begin{array}{l}0.014 \\
{[0.040]}\end{array}$ & $\begin{array}{l}0.004 \\
{[0.044]}\end{array}$ & & \\
\hline$K^{*}$ Export Share & & & & $\begin{array}{l}-0.021 \\
{[0.038]}\end{array}$ & & \\
\hline Export Share ${ }_{\text {High Income }}$ & & & & & $\begin{array}{l}0.021 \\
{[0.046]}\end{array}$ & $\begin{array}{l}0.001 \\
{[0.055]}\end{array}$ \\
\hline Export Share ${ }_{\text {Low Income }}$ & & & & & $\begin{array}{l}0.004 \\
{[0.085]}\end{array}$ & $\begin{array}{l}0.005 \\
{[0.085]}\end{array}$ \\
\hline$K^{*}$ Export Share ${ }_{\text {High Income }}$ & & & & & & $\begin{array}{c}-0.031 \\
{[0.046]}\end{array}$ \\
\hline$K^{*}$ Export Share ${ }^{\text {Low Income }}$ & & & & & & $\begin{array}{l}0.022 \\
{[0.090]}\end{array}$ \\
\hline Observations & 11564 & 11562 & 11027 & 11027 & 11027 & 11027 \\
\hline $\mathrm{R}$-squared & 0.091 & 0.123 & 0.136 & 0.136 & 0.136 & 0.136 \\
\hline
\end{tabular}

Notes: The dependent variable is the firm output volatility, gvol. Robust standard errors in brackets. All specifications include 4 digit NACE Rev 1.1 sector and NUTS III region dummies.

* Significant at $10 \%$ level.

** Significant at $5 \%$ level.

*** Significant at $1 \%$ level. 
Table A.5

Weighted average product complexity $K^{w}-$ results.

\begin{tabular}{|c|c|c|c|c|c|c|c|c|}
\hline & [1] & {$[2]$} & [3] & {$[4]$} & [5] & [6] & [7] & [8] \\
\hline & Baseline & & & The role of fir & port intensity & & & \\
\hline$K^{w}$ & $\begin{array}{c}-0.080^{* * * *} \\
{[0.019]}\end{array}$ & $\begin{array}{c}-0.073^{* * * *} \\
{[0.018]}\end{array}$ & $\begin{array}{c}-0.061^{* * *} \\
{[0.018]}\end{array}$ & $\begin{array}{c}-0.060^{* * * *} \\
{[0.019]}\end{array}$ & $\begin{array}{c}-0.062^{* * * *} \\
{[0.019]}\end{array}$ & $\begin{array}{c}-0.068^{* * *} \\
{[0.018]}\end{array}$ & $\begin{array}{c}-0.066^{* * *} \\
{[0.019]}\end{array}$ & $\begin{array}{c}-0.068^{* * *} \\
{[0.019]}\end{array}$ \\
\hline Size & & $\begin{array}{c}-0.148^{* * *} \\
{[0.010]}\end{array}$ & $\begin{array}{c}-0.116^{* * *} \\
{[0.011]}\end{array}$ & $\begin{array}{c}-0.119^{* * *} \\
{[0.011]}\end{array}$ & $\begin{array}{c}-0.116^{* * * *} \\
{[0.011]}\end{array}$ & $\begin{array}{c}-0.096^{* * *} \\
{[0.012]}\end{array}$ & $\begin{array}{c}-0.107^{* * *} \\
{[0.012]}\end{array}$ & $\begin{array}{c}-0.096^{* * *} \\
{[0.012]}\end{array}$ \\
\hline Labour_Productivity & & & $\begin{array}{c}-0.011 \\
{[0.009]}\end{array}$ & $\begin{array}{c}-0.01 \\
{[0.009]}\end{array}$ & $\begin{array}{c}-0.01 \\
{[0.009]}\end{array}$ & $\begin{array}{c}-0.007 \\
{[0.009]}\end{array}$ & $\begin{array}{c}-0.009 \\
{[0.009]}\end{array}$ & $\begin{array}{c}-0.007 \\
{[0.009]}\end{array}$ \\
\hline Importer & & & $\begin{array}{c}-0.064^{* *} \\
{[0.028]}\end{array}$ & $\begin{array}{c}-0.072^{* *} \\
{[0.028]}\end{array}$ & $\begin{array}{c}-0.065^{* *} \\
{[0.028]}\end{array}$ & $\begin{array}{r}-0.048^{*} \\
{[0.028]}\end{array}$ & $\begin{array}{c}-0.060^{* *} \\
{[0.028]}\end{array}$ & $\begin{array}{r}-0.048^{*} \\
{[0.028]}\end{array}$ \\
\hline Investor ${ }^{\text {Tangibles }}$ & & & $\begin{array}{c}-0.110^{* * *} \\
{[0.026]}\end{array}$ & $\begin{array}{l}0.007^{* * *} \\
{[0.001]}\end{array}$ & $\begin{array}{c}-0.110^{* * * *} \\
{[0.026]}\end{array}$ & $\begin{array}{c}-0.107^{* * *} \\
{[0.026]}\end{array}$ & $\begin{array}{c}-0.111^{* * *} \\
{[0.026]}\end{array}$ & $\begin{array}{c}-0.107^{* * *} \\
{[0.026]}\end{array}$ \\
\hline Investor $^{\text {Intangibles }}$ & & & $\begin{array}{c}0.013 \\
{[0.022]}\end{array}$ & $\begin{array}{c}0.119 \\
{[0.364]}\end{array}$ & $\begin{array}{c}0.013 \\
{[0.022]}\end{array}$ & $\begin{array}{c}0.018 \\
{[0.022]}\end{array}$ & $\begin{array}{c}0.015 \\
{[0.022]}\end{array}$ & $\begin{array}{c}0.018 \\
{[0.022]}\end{array}$ \\
\hline Wage & & & $\begin{array}{c}-0.088^{* * * *} \\
{[0.021]}\end{array}$ & $\begin{array}{c}-0.093^{* * *} \\
{[0.021]}\end{array}$ & $\begin{array}{c}-0.089^{* * * *} \\
{[0.021]}\end{array}$ & $\begin{array}{c}-0.077^{* * *} \\
{[0.022]}\end{array}$ & $\begin{array}{c}-0.086^{* * *} \\
{[0.021]}\end{array}$ & $\begin{array}{c}-0.076^{* * *} \\
{[0.022]}\end{array}$ \\
\hline Export_Share & & & & $\begin{array}{c}0.023 \\
{[0.040]}\end{array}$ & & & & \\
\hline Export_Share ${ }^{\text {High_Income }}$ & & & & & $\begin{array}{r}-0.001 \\
{[0.044]}\end{array}$ & & & \\
\hline Export_Share ${ }^{\text {Low_Income }}$ & & & & & $\begin{array}{c}0.145 \\
{[0.092]}\end{array}$ & & & \\
\hline$N^{\text {Destinations }}$ & & & & & & $\begin{array}{c}-0.052^{* * *} \\
{[0.010]}\end{array}$ & & $\begin{array}{c}-0.054^{* * *} \\
{[0.013]}\end{array}$ \\
\hline$N^{\text {Products }}$ & & & & & & & $\begin{array}{c}-0.025^{* *} \\
{[0.010]}\end{array}$ & $\begin{array}{c}0.003 \\
{[0.012]}\end{array}$ \\
\hline Observations & 4174 & 4174 & 4055 & 4055 & 4055 & 4055 & 4055 & 4055 \\
\hline $\mathrm{R}$-squared & 0.179 & 0.226 & 0.238 & 0.235 & 0.239 & 0.243 & 0.24 & 0.243 \\
\hline
\end{tabular}

Notes: The dependent variable is the firm output volatility, gvol.

Robust standard errors in brackets. All specifications include 4 digit NACE Rev 1.1 sector and NUTS III region dummies.

* Significant at $10 \%$ level.

** Significant at 5\% level.

*** Significant at $1 \%$ level.

Table A.6

Weighted average product complexity $K^{w}$ - further robustness checks.

\begin{tabular}{|c|c|c|c|c|c|c|c|c|c|}
\hline & {$[1]$} & {$[2]$} & [3] & {$[4]$} & [5] & [6] & [7] & [8] & [9] \\
\hline & \multirow[t]{2}{*}{ Averaged regressors ${ }^{\mathrm{a}}$} & \multirow[t]{2}{*}{ Prody } & \multirow[t]{2}{*}{ Average growth } & \multirow[t]{2}{*}{ Region-sector FEs } & \multirow[t]{2}{*}{ Log(residual) } & AR1 & AR2 & AR1 & AR2 \\
\hline & & & & & & \multicolumn{2}{|l|}{ Surviving firms } & All firms & \\
\hline$K^{w}$ & $\begin{array}{c}-0.060^{* * *} \\
{[0.023]}\end{array}$ & $\begin{array}{c}-0.038^{*} \\
{[0.021]}\end{array}$ & $\begin{array}{c}-0.055^{* * *} \\
{[0.018]}\end{array}$ & $\begin{array}{c}-0.065^{* * *} \\
{[0.023]}\end{array}$ & $\begin{array}{c}-0.115^{* * *} \\
{[0.037]}\end{array}$ & $\begin{array}{c}-0.114^{* * *} \\
{[0.043]}\end{array}$ & $\begin{array}{c}-0.145^{* * *} \\
{[0.050]}\end{array}$ & $\begin{array}{c}-0.074^{*} \\
{[0.038]}\end{array}$ & $\begin{array}{c}-0.115^{* *} \\
{[0.049]}\end{array}$ \\
\hline Size & $\begin{array}{c}-0.131^{* * *} \\
{[0.013]}\end{array}$ & $\begin{array}{c}-0.117^{* * * *} \\
{[0.011]}\end{array}$ & $\begin{array}{c}-0.131^{* * *} \\
{[0.011]}\end{array}$ & $\begin{array}{c}-0.107^{* * *} \\
{[0.014]}\end{array}$ & $\begin{array}{c}-0.241^{* * *} \\
{[0.021]}\end{array}$ & $\begin{array}{c}-0.238^{* * * *} \\
{[0.024]}\end{array}$ & $\begin{array}{c}-0.270^{* * *} \\
{[0.028]}\end{array}$ & $\begin{array}{c}-0.238^{* * *} \\
{[0.021]}\end{array}$ & $\begin{array}{c}-0.244^{* * *} \\
{[0.026]}\end{array}$ \\
\hline Labour_Productivity & $\begin{array}{c}-0.035 \\
{[0.023]}\end{array}$ & $\begin{array}{c}-0.011 \\
{[0.009]}\end{array}$ & $\begin{array}{c}-0.018^{* *} \\
{[0.009]}\end{array}$ & $\begin{array}{c}-0.007 \\
{[0.011]}\end{array}$ & $\begin{array}{c}-0.019 \\
{[0.021]}\end{array}$ & $\begin{array}{c}-0.04 \\
{[0.026]}\end{array}$ & $\begin{array}{c}-0.077^{* *} \\
{[0.032]}\end{array}$ & $\begin{array}{c}-0.084^{* * * *} \\
{[0.023]}\end{array}$ & $\begin{array}{c}-0.099^{* * *} \\
{[0.032]}\end{array}$ \\
\hline Importer & $\begin{array}{c}-0.123^{* *} \\
{[0.053]}\end{array}$ & $\begin{array}{c}-0.069^{* *} \\
{[0.028]}\end{array}$ & $\begin{array}{c}-0.061^{* *} \\
{[0.028]}\end{array}$ & $\begin{array}{r}-0.066^{*} \\
{[0.035]}\end{array}$ & $\begin{array}{c}-0.210^{* * * *} \\
{[0.053]}\end{array}$ & $\begin{array}{c}-0.229^{* * * *} \\
{[0.059]}\end{array}$ & $\begin{array}{c}-0.250^{* * * *} \\
{[0.072]}\end{array}$ & $\begin{array}{c}-0.185^{* * *} \\
{[0.050]}\end{array}$ & $\begin{array}{c}-0.247^{* * *} \\
{[0.065]}\end{array}$ \\
\hline Investor Tangibles & $\begin{array}{c}0.018^{* * * *} \\
{[0.007]}\end{array}$ & $\begin{array}{c}-0.106^{* * * *} \\
{[0.026]}\end{array}$ & $\begin{array}{c}-0.108^{* * *} \\
{[0.025]}\end{array}$ & $\begin{array}{c}-0.107^{* * *} \\
{[0.032]}\end{array}$ & $\begin{array}{c}-0.189^{* * * *} \\
{[0.048]}\end{array}$ & $\begin{array}{c}-0.194^{* * * *} \\
{[0.055]}\end{array}$ & $\begin{array}{c}-0.216^{* * *} \\
{[0.066]}\end{array}$ & $\begin{array}{c}-0.214^{* * * *} \\
{[0.047]}\end{array}$ & $\begin{array}{c}-0.266^{\text {**** }} \\
{[0.060]}\end{array}$ \\
\hline Investor Intangibles $^{\text {In }}$ & $\begin{array}{c}0.826 \\
{[0.861]}\end{array}$ & $\begin{array}{c}0.014 \\
{[0.022]}\end{array}$ & $\begin{array}{c}0.02 \\
{[0.021]}\end{array}$ & $\begin{array}{c}-0.003 \\
{[0.026]}\end{array}$ & $\begin{array}{c}-0.036 \\
{[0.038]}\end{array}$ & $\begin{array}{c}-0.028 \\
{[0.043]}\end{array}$ & $\begin{array}{c}0.028 \\
{[0.050]}\end{array}$ & $\begin{array}{r}-0.036 \\
{[0.037]}\end{array}$ & $\begin{array}{c}0.013 \\
{[0.047]}\end{array}$ \\
\hline Wage & $\begin{array}{c}-0.046 \\
{[0.035]}\end{array}$ & $\begin{array}{c}-0.092^{* * *} \\
{[0.021]}\end{array}$ & $\begin{array}{c}-0.095^{* * *} \\
{[0.021]}\end{array}$ & $\begin{array}{c}-0.089^{* * *} \\
{[0.026]}\end{array}$ & $\begin{array}{c}-0.180^{* * * *} \\
{[0.045]}\end{array}$ & $\begin{array}{c}-0.190^{* * *} \\
{[0.053]}\end{array}$ & $\begin{array}{c}-0.047 \\
{[0.063]}\end{array}$ & $\begin{array}{c}-0.151^{* * *} \\
{[0.046]}\end{array}$ & $\begin{array}{c}-0.058 \\
{[0.060]}\end{array}$ \\
\hline Average_Growth & & & $\begin{array}{c}-0.766^{* * *} \\
{[0.072]}\end{array}$ & & & & & & \\
\hline Observations & 2663 & 4051 & 4055 & 4055 & 20479 & 16241 & 12190 & 22000 & 14467 \\
\hline R-squared & 0.275 & 0.237 & 0.27 & 0.42 & 0.079 & 0.091 & 0.086 & 0.079 & 0.082 \\
\hline
\end{tabular}

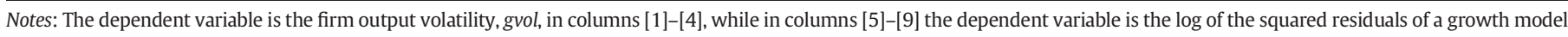
with firm and year fixed effects. Robust standard errors in brackets.

All specifications include 4 digit NACE Rev 1.1 sector dummies and NUTS III region fixed effects. Specifications in columns [5]-[9] include also year dummies.

* Significant at $10 \%$ level.

** Significant at $5 \%$ level.

*** Significant at $1 \%$ level.

a In this specification Investor ${ }^{\text {Tangibles }}$ and Investor ${ }^{\text {Intangibles }}$ represent respectively the share of tangible and intangible investments over output averaged over the period. 
Table A.7

Variables names and description.

\begin{tabular}{|c|c|}
\hline Label and definition & Description \\
\hline \multicolumn{2}{|l|}{ Product market conditions } \\
\hline$\sigma_{i}=, \log \left[\frac{\sum_{p=1}^{P_{i}} \sigma_{p}}{P_{i}}\right]$ & $\begin{array}{l}\text { Average elasticity of substitution across all products in a firm's export basket in year 2002. Product level } \\
\text { substitution elasticities, } \sigma_{p} \text {, are retrieved at the } 5 \text { digit SITC level from the Broda and Weinstein (2006)'s } \\
\text { estimates for the U.S. economy and converted into } 2002 \text { HS classification. Due to the presence of some } \\
\text { implausible extreme values we trimmed the upper and lower } 1 \% \text { of the distribution. Sources: Broda and } \\
\text { Weinstein (2006) and Turkstat. }\end{array}$ \\
\hline Concentration $_{i}^{\text {Supply }}=\frac{\sum_{p=1}^{P_{i}} \text { Herfindahl }_{p}}{P_{p}}$ & Average concentration of product supply across all products in firm i's export basket in year 2002. Here, \\
\hline & $\begin{array}{l}\text { Herfindahl }_{p}=\sum_{c=1}^{C} \frac{\text { Herfindahl }_{p c}}{C} \text { is a product level Herfindahl index obtained as the simple average of } \\
\text { country-product specific Herfinahl indexes, Herfindahl } l_{p c} \text {, across all countries } c=1, \ldots, C \text { for which informa- } \\
\text { tion on the HS } 2002 \text { product export concentration across domestic firms is available. Sources: Exporter } \\
\text { Dynamics Database (EDD, World Bank (Fernandes et al., 2016)) and Turkstat. }\end{array}$ \\
\hline Consumption $_{i}^{\text {Highlncome }}=\frac{\sum_{p=1}^{P_{i}} \frac{\text { Highhncomefconomiestmports }}{\text { Wordlmports }_{p}}}{P_{i}}$ & $\begin{array}{l}\text { Average share of imports by high income economies across all products in firm i's export basket in year } \\
\text { 2002. To build the indicator we retrieve } 6 \text { digit HS } 2002 \text { level world and high income economies' imports } \\
\text { for year } 2002 \text { from the COMTRADE-WITS database. Sources: WITS-COMTRADE and Turkstat. }\end{array}$ \\
\hline Volatility Demand & $\begin{array}{l}\text { Average product demand volatility across all products in firm } i \text { 's export basket in year 2002. Product level } \\
\text { demand volatility is obtained as the per capita income volatility, Income Volatility, over the 1998-2002 }\end{array}$ \\
\hline Volathly $_{i}=P_{i}$ & $\begin{array}{l}\text { period averaged across all countries } c=1, \ldots, C \text { importing the product, each one weighted with the } 2002 \\
\text { import share. } 6 \text { digit } 1996 \text { HS import data have been converted into } 2002 \text { HS. Sources: BACI, } 2014 \text { WBDI } \\
\text { and Turkstat }\end{array}$ \\
\hline \multicolumn{2}{|l|}{ Technological factors } \\
\hline Human Capital ${ }_{i}^{\text {Intensity }}=\frac{\sum_{p=1}^{P_{i}} \text { Revealed Human Capital Intensity } y_{p}^{\text {Std }}}{P_{i}}$ & $\begin{array}{l}\text { Average standardised human capital intensity across all products in firm i's export basket in year 2002. The } \\
\text { Revealed Human Capital Intensity Index is available from UNCTAD at } 6 \text { digit HS product level and measures } \\
\text { weighted average years of schooling of product's exporting countries. Sources: Unctad Data set of Revealed } \\
\text { Factor Intensity Indices (Shirotori et al., 2010) and Turkstat. }\end{array}$ \\
\hline$N_{i}^{\text {Input }}=, \log \left[\frac{\sum_{p=1}^{P_{i}} \text { Numberofinputsusedinproduction }_{p}}{P_{i}}\right]$ & $\begin{array}{l}\text { Average number of inputs employed in the production process across all products in firm } i \text { 's export } \\
\text { basket in year 2002. It is computed from the } 2002 \text { US commodity-by-commodity Total Requirements } \\
\text { Input-Output tables, available at IO code level which is converted to HS } 2002 \text { level. Differently from } \\
\text { standard IO tables, the Total Requirement ones also take into account the indirect use of inputs in the } \\
\text { production of each commodity. This measure, thus, rests on a broader definition of inputs although direct } \\
\text { and indirect inputs were only considered when they accounted for at least } 1 / 1000 \text { of a dollar of production } \\
\text { of each commodity available to final consumption. Sources: Turkstat Sources and BEA US IO-Tables, } \\
\text { http://www.bea.gov/industry/io_benchmark.htm }\end{array}$ \\
\hline
\end{tabular}

\section{References}

Balassa, B., 1965. Trade liberalisation and revealed comparative advantage. J. Financ. Econ. $33,99-123$

Becker, G., Murphy, K., 1992. The division of labor, coordination costs, and knowledge. Q. J. Econ. 107, 1137-1160.

Blanchard, O., Simon, J., 2001. The long and large decline in U.S. output volatility. Brook. Pap. Econ. Act. 32, 135-174.

Broda, C., Weinstein, D.E., 2006. Globalization and the gains from variety. Q. J. Econ. 121, 541-585.

Buch, C.M., Döpke, J., Strotmann, H., 2009. Does export openness increase firm-level output volatility? World Econ. 32, 531-551.

Cadot, O., Carrere, C., Strauss-Kahn, V., 2011. Export diversification: what's behind the hump. Rev. Econ. Stat. 93, 590-605.

Costinot, A., 2009. On the origins of comparative advantage. J. Int. Econ. 77, 255-264.

Fernandes, A., Freund, C., Pierola, M., 2016. Exporter behavior, country size and stage of development: evidence from the exporter dynamics database. J. Dev. Econ. 119, 121-137.

García-Vega, M., Guariglia, A., Spaliara, M.E., 2012. Volatility, financial constraints, and trade. Int. Rev. Econ. Financ. 21, 57-76.

di Giovanni, J., Levchenko, A.A., 2011. The Risk Content of Exports: A Portfolio View of International Trade. NBER International Seminar on Macroeconomics 2011. National Bureau of Economic Research, Inc., pp. 97-151 (NBER Chapters).

di Giovanni, J., Levchenko, A.A., 2012. Country size, international trade, and aggregate fluctuations in granular economies. J. Polit. Econ. 120, 1083-1132.

Hallak, J.C., 2006. Product quality and the direction of trade. J. Int. Econ. 68, 238-265.

Hausmann, R., Hidalgo, C.A., 2009. The building blocks of economic complexity. Proc. Natl. Acad. Sci. 106, 10570-10575.

Hausmann, R., Hwang, J., Rodrik, D., 2007. What you export matters. J. Econ. Growth 12, $1-25$.

Hidalgo, C., 2009. The dynamics of economic complexity and the product space over a 42 year period. Working Papers 189. Center for International Development, Harvard University.

Hnatkovska, V., Loayza, N., 2004. Volatility and growth. Policy Research Working Paper Series 3184. The World Bank.

Imbs, J., Wacziarg, R., 2003. Stages of diversification. Am. Econ. Rev. 93, 63-86.

Irvine, P.J., Pontiff, J., 2009. Idiosyncratic return volatility, cash flows, and product market competition. Rev. Financ. Stud. Soc. Financ. Stud. 22, 1149-1177.
Kalemli-Ozcan, S., Sorensen, B., Volosovych, V., 2014. Deep financial integration and volatility. J. Eur. Econ. Assoc.

Koren, M., Tenreyro, S., 2007. Volatility and development. Q. J. Econ. 122, 243-287.

Koren, M., Tenreyro, S., 2013. Technological diversification. Am. Econ. Rev. 103, 378-414.

Kraay, A., Ventura, J., 2007. Comparative advantage and the cross-section of business cycles. J. Eur. Econ. Assoc. 5, 1300-1333.

Krishna, P., Levchenko, A.A., 2013. Comparative advantage, complexity, and volatility. J. Econ. Behav. Organ. 94, 314-329.

Levchenko, A.A., 2007. Institutional quality and international trade. Rev. Econ. Stud. 74, 791-819.

Lin, S.C., Kim, D.H., 2014. The link between economic growth and growth volatility. Empir. Econ. 46, 43-63.

Lo Turco, A., Maggioni, D., 2014. The micro evolution of trade and turnover in Turkey under the global crisis. Econ. Syst.

Nocke, V., Yeaple, S., 2006. Globalization and Endogenous Firm Scope. NBER Working Papers 12322. National Bureau of Economic Research, Inc.

Norrbin, S.C., Yigit, F.P., 2005. The robustness of the link between volatility and growth of output. Rev. World Econ. (Weltwirtschaftliches Arch.) 141, 343-356.

Nunn, N., 2007. Relationship-specificity, incomplete contracts, and the pattern of trade. Q. J. Econ. 122, 569-600.

Poncet, S., de Waldemar, F.S., 2013. Export upgrading and growth: the prerequisite of domestic embeddedness. World Dev. 51, 104-118.

Ramey, G., Ramey, V.A., 1995. Cross-country evidence on the link between volatility and growth. Am. Econ. Rev. 85, 1138-1151.

Rodrik, D., 2006. What's so special about China's Exports? China World Econ. 14, 1-19.

Shirotori, M., Tumurchudur, B., Cadot, O., 2010. Revealed Factor Intensity Indices at the Product Level. UNCTAD Blue Series Papers 44. United Nations Conference on Trade and Development.

Stanley, M.H., Amaral, L.A., Buldyrev, S.V., Havlin, S., Leschhorn, H., Maass, P., Salinger, M.A., Stanley, H.E., 1996. Scaling behaviour in the growth of companies. Nature $379,804-806$.

Sutton, J., 2002. The variance of firm growth rates: the 'scaling' puzzle. Phys. A 312, 577-590.

Tacchella, A., Cristelli, M., Caldarelli, G., Gabrielli, A., Pietronero, L., 2013. Economic complexity: conceptual grounding of a new metrics for global competitiveness. J. Econ. Dyn. Control. 37, 1683-1691.

Vannoorenberghe, G., 2012. Firm-level volatility and exports. J. Int. Econ. 86, 57-67. 